\title{
Index of protection of the interests of consumers of the financial services market
}

\section{Olimkhon Furkat Ugly Alikariev}

$\mathrm{PhD}$, Associate Professor, project manager, Alliance Textile Manufacturers' Association of Light Industry, Uzbekistan.

\section{Serhiy Poliakh}

Department of Finance and Banking, Cherkasy Educational and Scientific Institute of the SHEI "Banking University", Ukraine.

(C) The Authors, 2018. This article is published with open access at Sumy State University.

\begin{abstract}
The world practice shows that active activity of international organizations in the direction of improving the system of protection of the rights of consumers of financial services gives first positive results after the crisis of 2008-2009. However, the theoretical basis, declared by international organizations, does not always coincide with the actual state of events in countries with different levels of economic and social development. This problem requires a more complex solution with the use of more flexible tools. In this article, key regulatory provisions were analyzed, which are currently regulating the process of providing the system for protecting the rights of consumers of financial services. Based on world experience, it is suggested to use the so-called index of the safity of customers of the finacial services market (ISCF), which is calculated on the basis of variables, united by three structural units: financial literacy, financial consumer protection, financial inclusion, to assess the degree of customer protection. This index was calculated for 142 countries with different levels of economic development. According to the results, the highest value of the index was found in the countries with developed economies (Belgium, Great Britain, Canada, Portugal and France). It confirms that the level of the economic development correlates with ISCF and there is direct connection. So, as country is more economic developed it has higher ISCF.
\end{abstract}

Keywords: financial literacy, financial consumer protection, financial inclusion, index of the safity of customers of the finacial services market.

JEL Classification: D18, G21.

\section{Introduction}

Today, the problem of protecting the interests of consumers of the financial services market sounds particularly acute and is raised for discussions in many countries around the world. First and foremost, the problem of which body will carry out and bear responsibility for protecting the rights of consumers of the financial sector, as well as what a key guideline is when developing the approach to comprehensive assessment of the level of protection of consumers' interests, becomes more urgent.

In the world, the growing popularity has the concept that financial literacy, financial inclusion and financial consumer protection are three main vectors that determine the qualitative component of ensuring the adequate level of protection of the interests of consumers of the financial services market.

Financial literacy of the population today is important because modern financial products are becoming more accessible to the general public on the one hand, but on the other hand they are more complex in technological terms, which definitely affects their perception by consumers. So, individuals often have to decide on the level and structure of their savings. By saving too little, investing insufficiently or borrowing too much, individuals are thus at risk of losing their income The sufficient level of financial literacy of the population will allow to minimize the risk. Financial literacy is also important for society as a whole. Elected persons and politicians should determine the level of public debt, the amount of borrowing and the level of pensions. All these decisions are likely to be distorted if they are based on incomplete knowledge of key concepts of financial reporting. The effects of financial literacy are obviously becoming even more important for central banks, since they were empowered to ensure the higher level of financial stability. Financial stability is inextricably linked to the quality of financial decision-making in the economy. 
In 2005, the programme of The Financial Sector Reform and Strengthening Initiative (FIRST) was launched in the world, which identifies key vectors for financial institutions to work effectively with their clients. First, this is the clarity of the financial information provided, which will avoid a number of questions and claims from the consumer side regarding the features of this financial product or service. Secondly, high-quality financial products and services can be of great benefit to the consumer when offered by highly skilled workers, therefore, in parallel with the increase in the level of financial literacy of the population, it is necessary to pay attention to the professional skills of employees of financial institutions. Thirdly, it is necessarye to inform clients about their rights and to guarantee the system of reimbursement in connection with the occurrence of the situation of their financial losses due to mistakes made by staff. Fourthly, employees of financial institutions should be competent not only at the stage of providing financial service, but also to accompany the client throughout the period of its use.

The feature of FIRST programme is that it is a simplified version of the algorithm of actions aimed at protecting the interests of consumers of the financial services market, but does not provide concrete examples of how these vectors can be realized. Thus, the purpose of this article is to determine the index of the safety of customers of the finacial services market on the basis of key indicators of three units: financial literacy, financial inclusion and financial consumer protection.

\section{Literature review}

General issues related to the definition of the conceptual framework for protecting the interests of consumers of the financial services market began to disturb the world community at the end of the XX century and at the beginning of the XXI century, in particular, in the period of the formation of a common European financial and economic area. As a result, international organizations developed a number of regulatory documents, which laid the main provisions for regulating the rights of consumers of the financial services market in general and the banking system in particular. The list of the most important documents can include the development of such international organizations as Organisation for Economic Cooperation and Development Methods and Results (OECD) - Guiding Principles for Regulatory Quality and Performance (2005), Best Practices for the Formal Exchange of Information Between Competition Authorities in Hard Core Cartel Investigations (2005), Best Practices for the Formal Exchange of Information Between Competition Authorities in Hard Core Cartel Investigations (2005); Bank for International Settlements (BIS) - Basel Committee on Banking Supervision, Core Principles for Effective Banking Supervision (2002); World Bank - General Principles for International Remittance Services (2007); European Union (EU) - Directive concerning Unfair Business-to-Consumer Commercial Practices in the Internal Market, 2005/29/EC; Markets in Financial Instruments Directive/ Markets in Financial Instruments Regulation (MiFID I, MiFID II/ MiFIR - 2007, 2011). These and other documents created the basis for the development of this area also at the level of individual states.

The financial and economic crisis of 2008-2009, which has affected its negative consequences all over the world, has demonstrated the need to improve the system of protecting the interests of the consumers of the financial services market, since it is the greatest burden of the crisis that has fallen to them. Thus, in the last quarter of 2011, the world saw 10 key principles that should be the base of customer protection in the financial sector, developed by OECD experts, Financial Stability Board (FSB) and other international organizations. The initiators of this project were Finance Ministers of the G-20 countries. The 10 key OECD principles are as follows:

Legal, Regulatory and Supervisory Framework;

Role of Oversight Bodies;

$>$ Equitable and Fair Treatment of Consumers;

$>$ Disclosure and Transparency;

$>$ Financial Education and Awareness;

$>$ Responsible Business Conduct of Financial Services Providers and Authorised Agents;

$>$ Protection of Consumer Assets against Fraud and Misuse;

$>$ Protection of Consumer Data and Privacy;

$>$ Complaints Handling and Redress;

$>$ Competition.

These principles are the basis of all further research related to the protection of the interests of consumers in the financial segment. One of the features is that most of the academic works done in this area are created by expert groups within the framework of the activities of international organizations (OECD, World Bank, IMF, 
ECB and others), but are not individual developments. One of the most prominent projects that was prepared by World Bank specialists led by Susan L. Rutledge, Senior Private Sector Development Specialist in 2012, became Good Practices for Financial Consumer Protection. These "practices" represent a kind of instruction on how to effectively organize the process of protecting the rights and interests of financial sector consumers. The work consists of three parts. The first part provides a detailed analysis of existing international measures aimed at improving the customer protection process. The second part lists a total of 39 "practices" that should ensure the effective functioning of the financial consumer protection system. These "practices" are grouped according to 8 criteria:

$>$ Consumer Protection Institutions;

$>$ Disclosure and Sales Practices;

$>$ Customer Account Handling and Maintenance;

$>$ Privacy and Data Protection;

$>$ Dispute Resolution Mechanisms;

$>$ Guarantee and Compensation Schemes;

$>$ Financial Literacy \& Consumer Empowerment;

$>$ Competition.

The last part presents "practices" somewhat modified and adapted for use in the banking sector, stock market, insurance market and non-bank financial institutions. The developed recommendations in no way contradict the international standards of quality of service of clients of the financial sector and are supported by the relevant regulatory acts.

The Consultative Group to Assist the Poor (CGAP), one of the World Bank's departments, established in 1995 to carry out practical studies on the level of involvement of people from different countries in financial services, the willingness of financial institutions to provide these services, and to coordinate their activities with other financial institutions, represented by Denise Dias, introduced in 2013 technical recommendations for banking representatives on the topic "Implementing Consumer Protection in Emerging Markets and Developing Economies". These recommendations include real examples of how the banking supervision process is taking place in different countries, both in developed countries and in developing countries. Examples of interinstitutional integration in the development of the concept of financial consumer protection are presented. Different approaches to banking supervision are also presented in this paper. In particular, it is about creating the system for protecting the rights of financial sector clients based on a risk-oriented approach (experience in Peru is given). Also, the place and role of internal institutions in addition to the central banks of countries that should oversee the process of organization of financial consumer protection are determined in the work, and a list of those tools that can be used to assess the level of satisfaction of financial sector consumers is determined.

However, we can also present a number of individual works by researchers around the world who have tried to adapt and test the effectiveness of the implementation of the 10 key OECD principles for their national financial systems. American scientists Aaltonen and Markowski (2010), on the eve of the publication of the OECD principles, conducted research among the clients of major US banks on the subject of what their satisfaction with the use of banking services mostly dependent on, in particular, using credit cards. During the investigation, researchers found a close correlation between the degree of satisfaction with the use of credit cards and the safety of this process, which once again proves the importance and relevance of solving the problem of ensuring an adequate level of customer protection. Thus, the authors note that the customer's security also depends on the accuracy of the service process, and on the willingness of the client to be involved in the market of financial services. This conclusion, as well as the work of another scientist (Messy, 2012), served as a basis for the so-called triple concept of financial services customer confidence: financial literacy, financial inclusion, financial consumer protection.

Thus, Ali Polat and Abdulsalam A. Alsaif (2014) in their study sought to identify the most important of the 10 key principles for the functioning of the Saudi Arabia banking system and ways to improve the effectiveness of the chosen principles. 272 Saudi residents who are direct users of banking services in the country took part in the study. The final sample included the results of survey of 265 respondents. Using the method of main components, it was determined that it is the privacy of providing banking services that can provide the highest degree of security for customers of the banking system. In turn, this can be facilitated by three factors: conducting special educational trainings and courses on increasing financial literacy, periodic use of thematic 
media resources, as well as establishing communication between the bank and clients through electronic systems.

The Grady study (2012) focused on identifying key trends in the development of financial consumer protection system in the world in general and in Australia, in particular. The author notes that the declared principles of the OECD are more nominalistic, that is, they can not be used in the pure form of the financial system of an individual country, because they do not take into account its specifics. Another scientist (Williams, 2013) criticized the developed key principles, in particular, against the idea that the emergence of these principles radically changed the general idea of the process of regulating the financial market. The researcher states that some principles do not operate before or during the crisis, but are guided by the consequences that the subjects of the financial services market have suffered.

\section{Methodology and data}

As inputs, the study used statistical information of CGAP and the World Bank for the Financial Access 2010 database, Global Findex database and G20 Financial Inclusion Indicators of the World Bank, database of OECD/ INFE about Adult Financial Literacy for 142 countries in the world with different levels of economic development (methodology of IMF): countries with developed economies, transition economies, and emerging economies.

The index of the safety of customers of the finacial services market (ISCF) consists of three blocks: the willingness of clients to be simultaneously active participants of the financial services market and take a number of measures aimed at ensuring their rights, which is identified through the level of financial education of the adult population (readiness to be protected - RP ); the actual involvement of the population in the financial services market is expressed through the group of indicators of financial inclusion (inclusion to the protection scheme - IP); level of the quality of consumer protection financial market services, expressed through financial consumer protection indicators (quality of the protection - QP) (Table A - see Appendix).

So when we use the relevant statistical indicators to indicate the RP and IP determinants, the QP must be specifically calculated. One of the works (Poliakh S., Alikariyev N., 2017) presents the methodology used in determining the level of the quality of consumer protection financial market services.

In our case, the level of the quality of consumer protection financial market services, expressed through financial consumer protection indicators $(\mathrm{QP})$, will be determined as follows:

$$
\mathrm{QP}=\frac{1}{10}\left(\sum S C O R E_{10}\right)
$$

SCORE consists of ten indicators, which, in turn, consist of the following indicators:

\section{$\mathrm{SCORE}_{1}-$ Monitoring}

Mystery/ incognito shopping;

Interviews, focus groups and consumer research;

Require FIs to report statistics on number of complaints;

Operates call center to receive complaints;

$>$ Monitors providers' advertisements, websites, etc.;

On-site inspection and investigation of FIs.

$\mathrm{SCORE}_{2}-$ Enforcing

Issue warnings to financial institutions;

$>$ Require providers to refund excess charges;

$>$ Require providers to withdraw misleading advertisements;

$>$ Impose fines and penalties;

$>$ Issue public notice of violations;

$>$ Withdraw the offending provider's license to operate.

$\mathrm{SCORE}_{3}-$ Fair treatment

Deceptive advertising; 
Unfair or high-pressure selling practices;

Abusive collection practices;

Unauthorized use of client data or breach of client confidentiality;

No fair treatment provisions.

$\mathrm{SCORE}_{4}-$ Recourses

Yes, with financial ombudsman;

Yes, with general ombudsman;

Yes, mediation service.

$\mathrm{SCORE}_{5}-$ Standards for complaints resolution

Procedures and processes;

Timeliness of response;

Accessibility.

$\mathrm{SCORE}_{6}-$ Disclouser upon opening deposit

Annual percentage yield and interest rate;

Method of compounding;

Minimum balance requirement;

Fees and penalties;

Early withdrawal penalties.

$\mathrm{SCORE}_{7}-$ Disclouser upon opening credit

Annual percentage rate using a standard formula;

Fees;

Computation method (avg. balance, interest);

Required insurance.

$\mathrm{SCORE}_{8}-$ Disclouser upon opening general

Plain language requirement;

Local language requirement;

Prescribed, standardized disclosure format;

Recourse rights and processes.

SCORE $_{9}$ - Periodic disclouser upon opening deposit

Annual percentage yield calculation;

Amount of interest earned;

Fees improsed;

Account balance.

$\mathrm{SCORE}_{10}-$ Periodic disclouser upon opening credit

All account transactions during current period;

Annual percentage rate;

Interest charged for the period;

$>$ Fees charged for the period;

$>$ Minimum amount due;

$>$ Date due;

Outstanding balance.

If a specific indicator from the different SCOREj is executed for a particular country, then 1 is put opposite to it, if not - 0. Then, each SCOREj is assigned the degree of compliance. The results of the QP index obtained are presented in Table 1 . 
Table 1. The results of the index of the quality of consumer protection financial market services (QP), where $\mathrm{D}$ - countries with developed economies, $\mathrm{T}$ - countries with transition economies and $\mathrm{E}$ - countries with emerging economies

\begin{tabular}{|c|c|c|c|c|c|c|c|c|c|}
\hline Country & QP & Country & $\mathrm{QP}$ & Country & QP & Country & $\mathrm{QP}$ & Country & QP \\
\hline Italy (D) & 0.86 & Peru $(\mathrm{T})$ & 0.66 & Bolivia (T) & 0.53 & $\begin{array}{l}\text { Singapore } \\
\text { (D) }\end{array}$ & 0.36 & Namibia (T) & 0.07 \\
\hline Armenia (E) & 0.83 & $\begin{array}{l}\text { Mauritania } \\
\text { (T) }\end{array}$ & 0.66 & Gambia (T) & 0.53 & Liberia $(\mathrm{T})$ & 0.33 & Anguilla (T) & 0.03 \\
\hline Venezuela (T) & 0.83 & Ghana (T) & 0.66 & Finland (D) & 0.53 & Ukraine (E) & 0.33 & $\begin{array}{l}\text { Antigua and } \\
\text { Barbuda (T) }\end{array}$ & 0.03 \\
\hline Canada (D) & 0.80 & Pakistan (T) & 0.66 & Oman (T) & 0.50 & Sweden (D) & 0.30 & $\begin{array}{l}\text { Bangladesh } \\
\text { (T) }\end{array}$ & 0.03 \\
\hline Puerto Rico (D) & 0.80 & Albania (E) & 0.66 & El Salvador (T) & 0.50 & Benin (T) & 0.26 & $\begin{array}{l}\text { Bosnia and } \\
\text { Herzegovina } \\
\text { (E) }\end{array}$ & 0.03 \\
\hline Greece (D) & 0.80 & Tajikistan (E) & 0.63 & Lithuania (D) & 0.50 & $\begin{array}{l}\text { Burkina Faso } \\
\text { (E) (T) }\end{array}$ & 0.26 & China $(\mathrm{T})$ & 0.03 \\
\hline Taiwan (D) & 0.77 & $\begin{array}{l}\text { Afghanistan } \\
\text { (T) }\end{array}$ & 0.63 & Zambia(T) & 0.50 & $\begin{array}{c}\text { Cote d'Ivoire } \\
(\mathrm{T})\end{array}$ & 0.26 & Dominica (T) & 0.03 \\
\hline Hungary $(\mathrm{T})$ & 0.76 & Kuwait (T) & 0.63 & $\begin{array}{c}\text { Dominican } \\
\text { Republic }(\mathrm{T}) \\
\end{array}$ & 0.50 & $\begin{array}{c}\text { Guinee } \\
\text { Bissau (T) } \\
\end{array}$ & 0.26 & Georgia (E) & 0.03 \\
\hline Argentina (T) & 0.76 & Moldova (E) & 0.63 & Tunisia $(\mathrm{T})$ & 0.50 & Macedonia & 0.26 & Germany (D) & 0.03 \\
\hline Azerbaijan (E) & 0.76 & $\begin{array}{c}\text { United } \\
\text { Kingdom (D) }\end{array}$ & 0.63 & Jordan(T) & 0.50 & Mali (T) & 0.26 & Grenada $(\mathrm{T})$ & 0.03 \\
\hline Uruguay (T) & 0.76 & $\begin{array}{l}\text { Switzerland } \\
\text { (D) }\end{array}$ & 0.63 & Estonia (D) & 0.47 & Niger (T) & 0.26 & Iceland (D) & 0.03 \\
\hline Mexico (T) & 0.76 & Thailand $(\mathrm{T})$ & 0.63 & $\operatorname{Iran}(\mathrm{T})$ & 0.46 & Senegal $(\mathrm{T})$ & 0.26 & Montserrat (T) & 0.03 \\
\hline Mauritius (T) & 0.73 & Ecuador $(\mathrm{T})$ & 0.63 & Ireland (D) & 0.46 & Togo $(\mathrm{T})$ & 0.26 & Romania (T) & 0.03 \\
\hline Zimbabwe (T) & 0.73 & Morocco (T) & 0.63 & Philippines (T) & 0.46 & Uganda (T) & 0.23 & $\begin{array}{l}\text { St. Kitts and } \\
\text { Nevis (T) }\end{array}$ & 0.03 \\
\hline Uzbekistan (E) & 0.73 & Brazil (T) & 0.63 & Jamaica (T) & 0.46 & Belarus (E) & 0.23 & St. Lucia (T) & 0.03 \\
\hline Colombia $(\mathrm{T})$ & 0.73 & Indonesia $(\mathrm{T})$ & 0.60 & $\begin{array}{c}\text { Slovak } \\
\text { Republic (D) }\end{array}$ & 0.46 & Mongolia (T) & 0.23 & $\begin{array}{l}\text { St. Vincent } \\
\text { and the } \\
\text { Grenadines } \\
\text { (T) }\end{array}$ & 0.03 \\
\hline India $(\mathrm{T})$ & 0.73 & Korea $(\mathrm{T})$ & 0.60 & Vietnam $(\mathrm{T})$ & 0.46 & Norway (D) & 0.23 & Sudan (T) & 0.03 \\
\hline Chile (T) & 0.73 & $\begin{array}{l}\text { New Zealand } \\
\text { (D) }\end{array}$ & 0.60 & Hong Kong (D) & 0.43 & Syria $(\mathrm{T})$ & 0.23 & Tanzania $(\mathrm{T})$ & 0.03 \\
\hline Malaysia (T) & 0.73 & Rwanda (T) & 0.60 & Swaziland (T) & 0.43 & Sri Lanka $(\mathrm{T})$ & 0.20 & & \\
\hline Spain (D) & 0.73 & $\begin{array}{l}\text { Netherlands } \\
\text { (D) }\end{array}$ & 0.60 & $\begin{array}{c}\text { Kyrgyz } \\
\text { Republic (E) }\end{array}$ & 0.43 & Australia (D) & 0.20 & & \\
\hline Portugal (D) & 0.70 & Yemen $(\mathrm{T})$ & 0.60 & Botswana (T) & 0.43 & $\begin{array}{l}\text { Papua New } \\
\text { Guinea (T) }\end{array}$ & 0.20 & & \\
\hline South Africa (T) & 0.70 & $\begin{array}{c}\text { Cape Verde } \\
(\mathrm{T})\end{array}$ & 0.60 & Costa Rica (T) & 0.43 & Russia (E) & 0.20 & & \\
\hline Algeria $(\mathrm{T})$ & 0.70 & Ethiopia (T) & 0.60 & Slovenia (D) & 0.43 & Turkey (T) & 0.20 & & \\
\hline Croatia $(\mathrm{T})$ & 0.70 & Lao PDR (T) & 0.56 & Kazakhstan (E) & 0.40 & Cambodia (E) & 0.17 & & \\
\hline Nicaragua (T) & 0.70 & $\begin{array}{c}\text { Sierra Leone } \\
(\mathrm{T})\end{array}$ & 0.56 & Guatemala (T) & 0.40 & Lesotho (T) & 0.17 & & \\
\hline Nigeria $(\mathrm{T})$ & 0.70 & Honduras (T) & 0.53 & Japan (D) & 0.40 & Kenya $(\mathrm{T})$ & 0.17 & & \\
\hline Panama $(\mathrm{T})$ & 0.70 & Poland (T) & 0.53 & Latvia $(\mathrm{T})$ & 0.40 & Nepal (T) & 0.17 & & \\
\hline United States (D) & 0.70 & Bulgaria (E) & 0.53 & Madagascar (T) & 0.40 & $\begin{array}{l}\text { United Arab } \\
\text { Emirates (T) }\end{array}$ & 0.10 & & \\
\hline Belgium (D) & 0.66 & Israel (D) & 0.53 & Mozambique(T) & 0.36 & Burundi (T) & 0.07 & & \\
\hline Denmark (D) & 0.66 & Serbia (E) & 0.53 & $\begin{array}{l}\text { Czech Republic } \\
\text { (D) }\end{array}$ & 0.36 & Lebanon (T) & 0.07 & & \\
\hline France (D) & 0.66 & Austria (D) & 0.53 & Paraguay $(\mathrm{T})$ & 0.36 & Malawi (T) & 0.07 & & \\
\hline
\end{tabular}

Thus, the highest value of the index of the quality of consumer protection financial market services QP is observed in Italy, Armenia, Venezuela, Canada and Puerto Rico. Three of the five identified countries-leaders belong to developed economies, one to transition economies, and one to emerging economies. However, the nominal observance of the index of the quality of consumer protection financial market services does not mean that the interests of consumers in these countries are completely protected.

In order to calculate the index of the safity of customers of the finacial services market (ISCF) besides QP we use the determinants of RP and IP (Table 2). 
Table 2. Variables which are used to calculate the index of the safity of customers of the finacial services market (ISCF)

\begin{tabular}{|c|l|}
\hline Indicator & \\
\hline RP & Adults who are financially literate (\%) \\
\hline \multirow{4}{*}{ IP } & Financial Inclusion Reforms \\
\cline { 2 - 3 } & Accounts in the commercial banks per thousand adults (deposit) \\
\cline { 2 - 3 } & Accounts in the commercial banks per thousand adults (credit) \\
\cline { 2 - 3 } & Branches of the commercial banks per hundred thousand adults \\
\cline { 2 - 3 } & ATMs per hundred thousand adults \\
\cline { 2 - 3 } & POSs per hundred thousand adults \\
\cline { 2 - 3 } & Account (\% age 15+) \\
\hline
\end{tabular}

More detailed information about these indicators are in the Table B (see Appendix).

Before switching to the index of the safity of customers of the finacial services market (ISCF), the input variables from Table 2 need to be normalized (QP does not require valuation as its value is already from 0 to 1). Normalization of variables is carried out according to the following formula:

$d_{i}=\frac{b_{i}-b \min _{i}}{b \max _{i}-b \min _{i}}$

where $\mathrm{i}$ - variable value for each country;

$b_{i}-$ current value of the $i$-th variable;

$b \min _{i}-$ minimum value of the $\mathrm{i}$-th variable;

$b \max _{i}-$ maximum value of the $\mathrm{i}$-th variable.

Once the variables are normalized, you can switch to calculating the index of the safity of customers of the finacial services market (ISCF). To do this we use the following formula for calculating the inverse Euclidean distance, which allows you to obtain the integrated index:

$I_{i}=1-\frac{\sqrt{\left(1-d_{1}\right)^{2}+\left(1-d_{2}\right)^{2}+\ldots+\left(1-d_{n}\right)^{2}}}{\sqrt{n}}$,

where I - integral index;

i - variable value for each country;

$\mathrm{n}$ - total number of indicators included in the integral index;

$\mathrm{d}$ - normalized value of the indicator.

To calculate ISCF this formula will look like this:

$I S C F_{i}=1-\frac{\sqrt{(1-Q P)^{2}+(1-R P)^{2}+\ldots+(1-I P)^{2}}}{\sqrt{9}}$.

The table and schedule with the found index of the safity of customers of the finacial services market (ISCF) is presented below (Table 3 ). 
Table 3. The results of the index of the safity of customers of the finacial services market (ISCF), where D countries with developed economies, $\mathrm{T}$ - countries with transition economies and $\mathrm{E}$ - countries with emerging economies

\begin{tabular}{|c|c|c|c|c|c|c|c|c|c|}
\hline Country & QP & Country & QP & Country & $\mathrm{QP}$ & Country & QP & Country & $\mathrm{QP}$ \\
\hline Belgium (D) & 0.50 & Latvia (T) & 0.34 & $\begin{array}{l}\text { United Arab } \\
\text { Emirates (T) }\end{array}$ & 0.26 & Grenada $(\mathrm{T})$ & 0.20 & Syria $(\mathrm{T})$ & 0.15 \\
\hline United Kingdom (D) & 0.48 & Korea $(\mathrm{T})$ & 0.32 & Lebanon $(\mathrm{T})$ & 0.26 & Gambia $(\mathrm{T})$ & 0.20 & Tajikistan (E) & 0.15 \\
\hline Canada $(\mathrm{D})$ & 0.48 & $\begin{array}{c}\text { Czech } \\
\text { Republic (D) }\end{array}$ & 0.32 & Mongolia (T) & 0.25 & $\begin{array}{l}\text { Mozambique } \\
\text { (T) }\end{array}$ & 0.20 & Sudan $(\mathrm{T})$ & 0.14 \\
\hline Portugal (D) & 0.45 & Oman $(\mathrm{T})$ & 0.32 & Vietnam $(\mathrm{T})$ & 0.25 & Togo $(\mathrm{T})$ & 0.20 & Liberia (T) & 0.14 \\
\hline France (D) & 0.44 & Brazil (T) & 0.32 & $\begin{array}{l}\text { Papua New } \\
\text { Guinea }(\mathrm{T})\end{array}$ & 0.25 & Indonesia (T) & 0.19 & Georgia (E) & 0.14 \\
\hline Taiwan (D) & 0.43 & $\begin{array}{l}\text { Puerto Rico } \\
\text { (D) }\end{array}$ & 0.31 & $\begin{array}{l}\text { Montserrat } \\
\text { (T) }\end{array}$ & 0.24 & Benin $(\mathrm{T})$ & 0.19 & Lesotho (T) & 0.14 \\
\hline United States (D) & 0.43 & $\begin{array}{c}\text { Costa Rica } \\
(\mathrm{T})\end{array}$ & 0.31 & $\begin{array}{l}\text { Philippines } \\
\text { (T) }\end{array}$ & 0.24 & Senegal $(\mathrm{T})$ & 0.19 & Uganda $(\mathrm{T})$ & 0.14 \\
\hline Ireland (D) & 0.42 & Norway (D) & 0.31 & $\begin{array}{c}\text { Cape Verde } \\
(\mathrm{T})\end{array}$ & 0.24 & Jamaica $(\mathrm{T})$ & 0.19 & Zambia (T) & 0.14 \\
\hline Denmark (D) & 0.42 & Slovenia (D) & 0.31 & Ghana (T) & 0.24 & Niger $(T)$ & 0.19 & Namibia (T) & 0.14 \\
\hline Austria (D) & 0.41 & $\begin{array}{l}\text { St. Kitts and } \\
\text { Nevis (T) }\end{array}$ & 0.31 & $\begin{array}{l}\text { Kazakhstan } \\
\text { (E) }\end{array}$ & 0.24 & $\begin{array}{l}\text { El Salvador } \\
(\mathrm{T})\end{array}$ & 0.19 & Dominica $(\mathrm{T})$ & 0.13 \\
\hline Switzerland (D) & 0.41 & Poland (T) & 0.30 & $\begin{array}{l}\text { Madagascar } \\
(\mathrm{T})\end{array}$ & 0.23 & $\begin{array}{c}\text { Burkina Faso } \\
(\mathrm{T})\end{array}$ & 0.19 & $\begin{array}{l}\text { Sierra Leone } \\
\text { (T) }\end{array}$ & 0.12 \\
\hline Croatia (T) & 0.41 & Mauritius (T) & 0.30 & Ecuador $(\mathrm{T})$ & 0.23 & Tunisia $(\mathrm{T})$ & 0.19 & $\begin{array}{c}\text { Kyrgyz } \\
\text { Republic (E) }\end{array}$ & 0.12 \\
\hline New Zealand (D) & 0.40 & Thailand $(\mathrm{T})$ & 0.30 & $\begin{array}{c}\text { Cote d'Ivoire } \\
(\mathrm{T})\end{array}$ & 0.23 & Ethiopia (T) & 0.19 & Malawi (T) & 0.11 \\
\hline Greece (D) & 0.40 & Mexico (T) & 0.30 & Turkey $(\mathrm{T})$ & 0.22 & Mali (T) & 0.19 & $\begin{array}{l}\text { Bangladesh } \\
\text { (T) }\end{array}$ & 0.11 \\
\hline Bulgaria (E) & 0.40 & $\operatorname{Iran}(\mathrm{T})$ & 0.30 & Russia (E) & 0.22 & Armenia (E) & 0.18 & $\begin{array}{l}\text { Afghanistan } \\
\text { (T) }\end{array}$ & 0.10 \\
\hline Finland $(\mathrm{D})$ & 0.39 & Germany (D) & 0.30 & Belarus $(\mathrm{E})$ & 0.22 & Swaziland (T) & 0.18 & Cambodia(E) & 0.07 \\
\hline Israel (D) & 0.39 & Iceland (D) & 0.30 & $\begin{array}{l}\text { Macedonia } \\
\text { (E) }\end{array}$ & 0.22 & St. Lucia (T) & 0.18 & Yemen $(\mathrm{T})$ & 0.05 \\
\hline Malaysia (T) & 0.38 & Sweden (D) & 0.30 & $\begin{array}{l}\text { Mauritania } \\
\text { (T) }\end{array}$ & 0.22 & $\begin{array}{l}\text { Uzbekistan } \\
\text { (E) }\end{array}$ & 0.18 & Burundi (T) & 0.04 \\
\hline Hungary $(\mathrm{T})$ & 0.38 & Nigeria $(\mathrm{T})$ & 0.29 & Peru (T) & 0.22 & Bolivia (T) & 0.17 & & \\
\hline Italy (D) & 0.37 & Anguilla (T) & 0.29 & Rwanda (T) & 0.22 & Paraguay $(\mathrm{T})$ & 0.17 & & \\
\hline Spain (D) & 0.37 & Colombia (T) & 0.28 & Botswana (T) & 0.22 & Jordan $(\mathrm{T})$ & 0.17 & & \\
\hline Australia (D) & 0.36 & $\begin{array}{c}\text { Venezuela } \\
\text { (T) }\end{array}$ & 0.28 & $\begin{array}{l}\text { Guinee Bissau } \\
\text { (T) }\end{array}$ & 0.22 & Nepal (T) & 0.17 & & \\
\hline Slovak Republic (D) & 0.36 & Sri Lanka (T) & 0.28 & Lao PDR (T) & 0.21 & Romania (T) & 0.17 & & \\
\hline Lithuania (D) & 0.36 & $\begin{array}{l}\text { Nicaragua } \\
\text { (T) }\end{array}$ & 0.27 & Zimbabwe (T) & 0.21 & Pakistan (T) & 0.17 & & \\
\hline Netherlands (D) & 0.36 & Chile $(\mathrm{T})$ & 0.27 & Panama $(\mathrm{T})$ & 0.21 & Honduras (T) & 0.16 & & \\
\hline Estonia (D) & 0.35 & $\begin{array}{l}\text { Argentina } \\
\text { (T) }\end{array}$ & 0.27 & India $(\mathrm{T})$ & 0.21 & $\begin{array}{c}\text { Bosnia and } \\
\text { Herzegovina }\end{array}$ & 0.16 & & \\
\hline Japan (D) & 0.35 & Algeria (T) & 0.27 & $\begin{array}{l}\text { Azerbaijan } \\
\text { (E) }\end{array}$ & 0.21 & Kenya (T) & 0.16 & & \\
\hline Kuwait (T) & 0.35 & Serbia (E) & 0.26 & $\begin{array}{c}\text { Dominican } \\
\text { Republic }(\mathrm{T})\end{array}$ & 0.21 & Albania (E) & 0.15 & & \\
\hline Hong Kong (D) & 0.35 & Uruguay $(\mathrm{T})$ & 0.26 & $\begin{array}{l}\text { Antigua and } \\
\text { Barbuda (T) }\end{array}$ & 0.21 & Moldova (E) & 0.15 & & \\
\hline Singapore (D) & 0.35 & Morocco $(\mathrm{T})$ & 0.26 & Guatemala (T) & 0.21 & $\begin{array}{l}\text { St. Vincent } \\
\text { and the } \\
\text { Grenadines } \\
\text { (T) }\end{array}$ & 0.15 & & \\
\hline South Africa $(\mathrm{T})$ & 0.34 & Ukraine (E) & 0.26 & China (T) & 0.21 & Tanzania (T) & 0.15 & & \\
\hline
\end{tabular}

As we see, unlike the calculated index of the quality of consumer protection financial market services (QP) the list of leading countries has changed. Now it includes exclusively countries with developed economies: Belgium, Great Britain, Canada, Portugal and France. This result confirms that the level of the economic development correlates with ISCF and there is direct connection. So, as country is more economic developed it has higher ISCF. 


\section{Conclusions}

The system for protecting the customer rights should be the basis of the activities of modern financial institutions. As a result, a significant basis for regulating the activities of financial institutions in certain areas is a number of regulations issued internationally. Today there are top 10 key principles, which should be at the heart of protecting the rights of customers in the financial sector, developed in 2011 by OECD experts, Financial Stability Board (FSB) and other international organizations, commissioned by the finance ministers of the G-20 countries and developed by World Bank specialists the Good Practices for Financial Consumer Protection presented in 2012.

The main disadvantage in developing these provisions can be noted the fact they are of recommendatory and nominalist nature, that is, for their practical implementation, it is necessary to develop a special mechanism. This, in turn, complicates the process of assessing the quality of the system to ensure an adequate level of protecting the customers of the financial services market.

Thus, based on world experience, it is suggested in this paper to use the so-called index of the safity of customers of the finacial services market (ISCF) to evaluate the degree of customer protection, which was calculated on the basis of variables, united by three structural units: financial literacy, financial consumer protection, financial inclusion. This index was calculated for 142 countries with different levels of economic development. According to the results, the highest value of the index was found in the countries with developed economies, namely Belgium, Great Britain, Canada, Portugal and France. Many modern researchers to evaluate the protection of the interests of consumers of the financial services market are confined to variables that refer to financial consumer protection, but we have been proven that they are not indicative in the given situation.

In further research, it will be appropriate to trace the link between the index of the safity of customers of the finacial services market (ISCF) and indicators of financial stability of different countries of the world and to answer the question about the causal nature of the relationships between them.

\section{References}

1. Aaltonen, P.G., Markowski, E.P. and Kirchner, T.A. (2010). Ingredients of financial services customer satisfaction: the case of credit card services. Journal of Academy of Business and Economics. 10(3).

2. Abreu, Margarida and Mendes, Victor (2010). Financial Literacy and Portfolio Diversification, Quantitative Finance, 10(5), 515-528.

3. Allen, Franklin, Asli, Demirguc-Kunt, Leora, Klapper, and Maria, Soledad Martinez Peria (2012). The Foundations of Financial Inclusion: Understanding Ownership and Use of Formal Accounts, World Bank Policy Research Working Paper 6290.

4. Behrman, Jere R., Olivia, S. Mitchell, Cindy K. Soo, and David, Bravo, (2012). The Effects of Financial Education and Financial Literacy: How Financial Literacy Affects Household Wealth Accumulation, American Economic Review: Papers \&Proceedings, 102(3), 300-304.

5. Bond, R. (2010). Financial literacy and awareness in Ukraine: Facts and Conclusions, [in:] R. Bond, A. Kutsenko, N. Lozitskaya. - K.: USAID FINREP. Retrieved from: http://www.uaib.com.ua.

6. CGAP (2009). Financial Access 2009: Measuring Access to Financial Services around the World, Washington, DC: CGAP and the World Bank.

7. CGAP (2010). Financial Access 2010: The State of Financial Inclusion Through the Crisis, Washington, DC: CGAP and the World Bank Group.

8. Customer suitability in the retail sale of financial products and services (2008). The Joint Forum. Bank for International Settlements April. Retrieved from: https://www.iosco.org/lib rary/pubdocs/pdf/IOSCOPD268.pdf.

9. Demirguc-Kunt, Asli, Leora Klapper, Dorothe, Singer, and Peter, Van Oudheusden (2015). The Global Findex Database 2014: Measuring Financial Inclusion around the World, World Bank Policy Research Working Paper 7255.

10.Dias, D. (2013) Implementing Consumer Protection in Emerging Markets and Developing Economies A Technical Guide for Bank Supervisors 2013, CGAP/World Bank.

11.FSD-Kenya (2009). Definition of a Standard Measure for Consumer Interest Rates in Kenya: A Scoping Study, Nairobi: Kenya. Retrieved from: http://www.fsdkenya.or.

12.Grady, R. (2012). Consumer Protection in the financial sector: Recent regulatory developments. JASSA, 4, 36.

13.Grady, R. (2012). Consumer Protection in the financial sector: Recent regulatory developments. JASSA, 4, 36. 
14.Kang, K.H. (2015). Functions of Financial Consumer Protection Agency and Its Design in Korea, Review of Financial Information Studies, 4(1), 81-100.

15.Levitin, Adam J. (2013). The Consumer Financial Protection Bureau: An Introduction, Review of Banking and Financial Law, 32, 321-69. Retrieved from SSRN: http://ssrn.com/abstract=2199678 or http://dx.doi.org/10.2139/ssrn.2199678.

16.Mak, Vanessa (2012). The Myth of the "Empowered Consumer": Lessons from Financial Literacy Studies [Tisco Working Paper Series on Banking, Finance and Services No. 03/2012; Tilburg Law School Research Paper No. 03/2013], Retrieved from: http://ssrn.com/abstract=2077539 or http://dx.doi.org/10.2139/ssrn.2077539.

17.Messy, F.A. (2012). The latest development of globally recognized instruments on financial education and consumer protection, in 12th Tokyo Roundtable on Capital Market Reform in Asia: Tokyo, Japan. p. 12.

18.OECD (2012). G20 High-Level Principles on Financial Consumer Protection, Organisation for Economic Co-operation and Development: Paris. p. 7.

19.OECD (2014a). Effective Approaches to Support the Implementation of the Remaining G20 High-Level Principles of Financial Consumer Protection. Paris: OECD. Retrieved from: www.oecd.org/daf/fin/financial-education/G20-OECD-Financial-Consumer-Protection-.

20.OECD, G20 High-Level Principles on Financial Consumer Protection (2011). Organisation for Economic Co-operation and Development: Paris. p. 7.

21.Peterson, C. L. (2003). Truth, Understanding, and High-Cost Consumer Credit: The Historical Context of the Truth in Lending Act, Florida Law Review, 55, 807-903.

22.Polat, A., Alsaif, A. A. (2014). Consumer Protection in Banking: Investigating the 10 High Level Principles of G20 in Saudi Arabia, Journal of Applied Finance \& Banking, 4(3), 195-215.

23.Poliakh, S., Alikariyev N. (2017). Evaluation Quality of Consumer Protection by Financial Markets Services. Financial Markets, Institutions and Risks, 1(3), 75-81.

24.Porteous, D. (2009). Consumer Protection in Credit Markets, Policy Focus Note: 1, Financial Access Initiative. Retrieved from: [http://www.financialaccess.org].

25.Porteous, D. and Helms, B. (2005). Protecting Microfinance Borrowers, Focus Note No. 27, CGAP.

26.Shin, Y. (2015). Effect of Enforcement of Financial Consumer Protection on Financial Product Investment, International Conference on Social Science.

27.Shin, Y., Kim, J. (2015). Effect of Financial Consumer Protection Enforcement on Financial Product Investment in South Korean Market The SIJ Transactions on Industrial, Financial \& Business Management (IFBM), 3(8).

28.Sundararajan, V., Udaibir, Das, and Plamen, Yossifov (2003). Cross-Country and Cross-Sector Analysis of Transparency of Monetary and Financial Policies, IMF Working Paper 03/94 (Washington: International Monetary Fund).

29.Sundararajan, V., Udaibir, Das, and Plamen, Yossifov (2003). Cross-Country and Cross-Sector Analysis of Transparency of Monetary and Financial Policies, IMF Working Paper 03/94 (Washington: International Monetary Fund).

30.U.S. G.A.O. (2010). Consumer Finance: Factors Affecting the Financial Literacy of Individuals with Limited English Proficiency, United States Government Accountability Office, Report to Congressional Committees, GAO-10-518, Washington, DC.

31.Whitford, W.C. (1981). Structuring Consumer Protection Legislation to Maximize Effectiveness. Wis. L. Rev., p. 1018.

32.Williams, T. (2013). Who Wants to Watch? A Comment on the New International Paradigm of Financial Consumer Market Regulation. Seattle University Law Review. 36(2), 1217.

33.World Bank - FIRST Consumer Protection and Financial Literacy Program. Retrieved from: https://a2ii.org/sites/default/files/reports/world_bank-first_cpfl_program.pdf.

34.World Bank (2014). Global Survey on Consumer Protection and Financial Literacy: Oversight Frameworks and Practices in 114 Economies. Washington, DC: World Bank. Retrieved from: http://responsiblefinance.worldbank.org/ /media/GIAWB/FL/Documents/Publications/.

35.World Bank (2009). Good Practices for Financial Consumer Protection and Financial Literacy in Europe and Central Asia: A Diagnostic Tool, Washington DC: Private and Financial Sector Development Department Europe and Central Asia Region / The World Bank.

36.World Bank (2011). T., Good Practices for Financial Consumer Protection, Washington DC: International Bank for Reconstruction and Development / The World Bank.

37.Wright I.D.G.D. (2014). International Finance Regulation: The Quest for Financial Stability, Chapter 1, Editor: Ugeux, G, John Wiley \& Sons. 
Appendix

Table A - Indicators for evaluation of quality of the protection

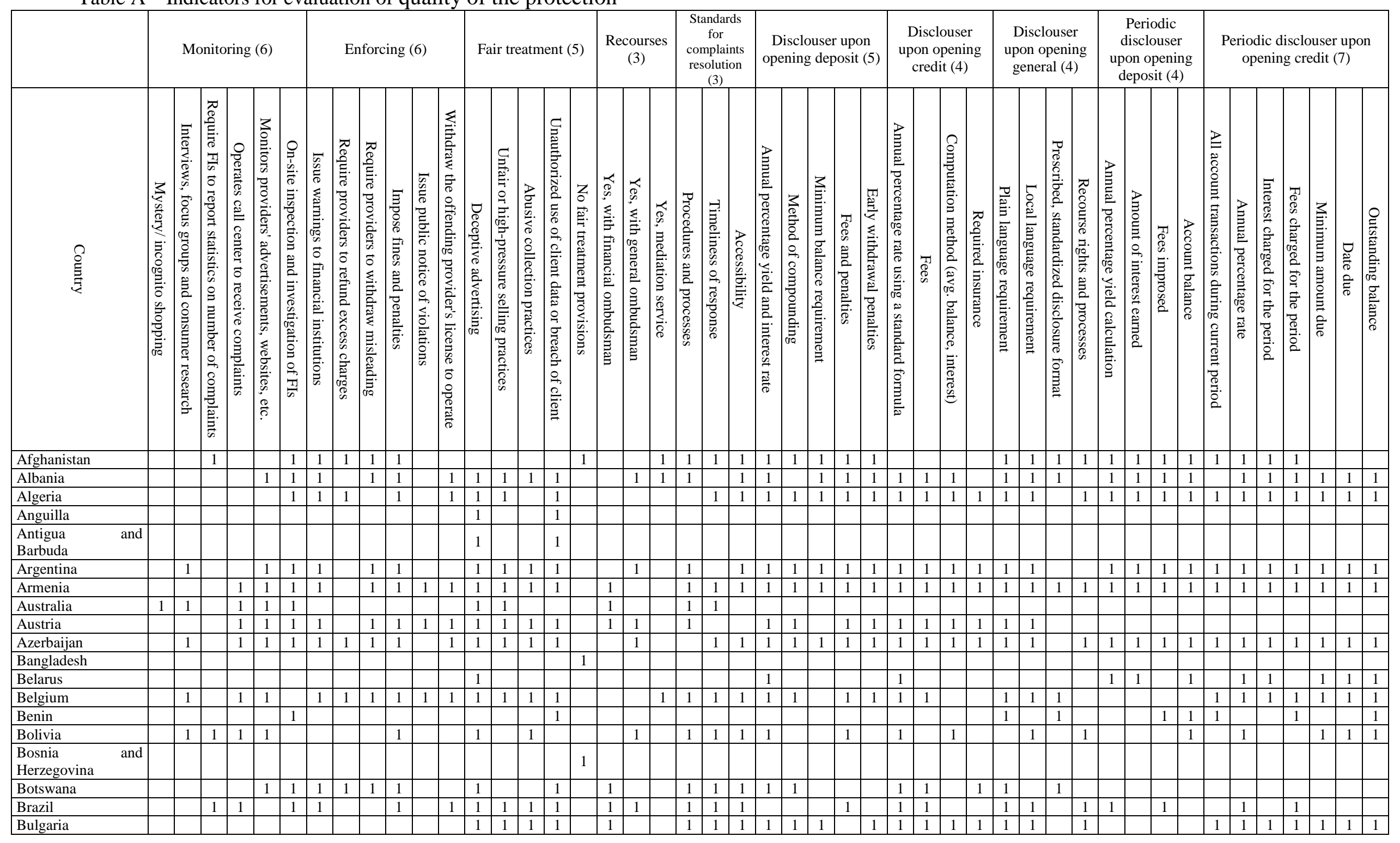


Burkina Faso

Burund

Cambodia

\begin{tabular}{l} 
Canada \\
\hline Cape Verde \\
\hline
\end{tabular}

Cape Verde

\begin{tabular}{l} 
Chile \\
\hline Ching \\
\hline
\end{tabular}

China

\begin{tabular}{l} 
China \\
\hline Colombia \\
\hline Cost Rica
\end{tabular}

\begin{tabular}{l} 
Colombia \\
\hline Costa Rica \\
\hline Cose
\end{tabular}

\begin{tabular}{l} 
Costa Rica \\
\hline Cote d'Ivoire
\end{tabular}

\begin{tabular}{|l}
\hline Croatia \\
\hline Czech Republic \\
\hline Dech
\end{tabular}

\begin{tabular}{l} 
Czech Republic \\
\hline Denmark
\end{tabular}

\begin{tabular}{l} 
Denmark \\
\hline Dominica \\
\hline
\end{tabular}

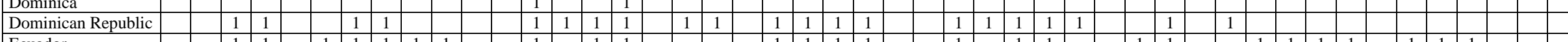

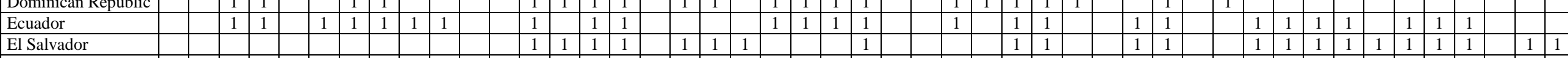

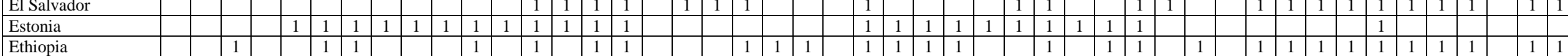

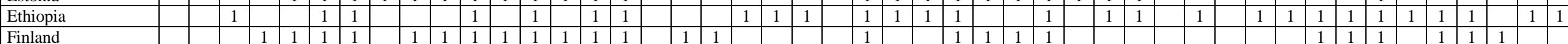

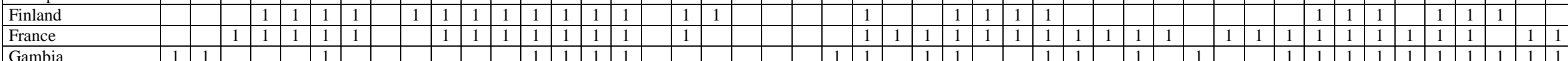

Georgia

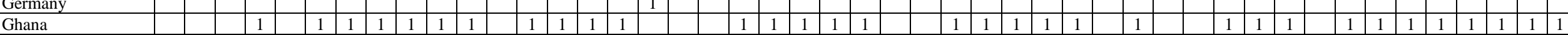

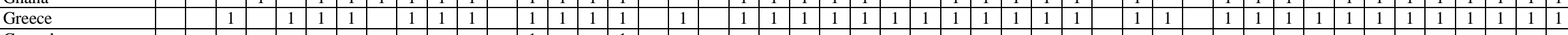

Grenada

Guatemala

Guinee Bissau

Honduras

\begin{tabular}{|l}
\hline Hong Kong \\
\hline
\end{tabular}

\begin{tabular}{l} 
Hong Kong \\
\hline Hungary
\end{tabular}

\begin{tabular}{|l}
\hline Hungary \\
\hline Iceland \\
\hline India \\
\hline Indonesia \\
\hline
\end{tabular}

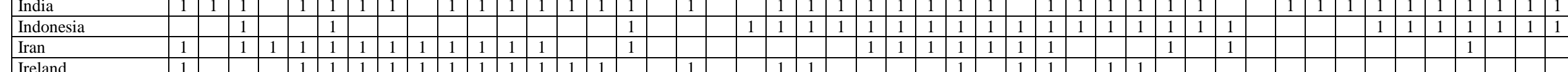
\begin{tabular}{llllllllllllllllllllllll}
1 & 1 & 1 & 1 & 1 & 1 & 1 & & 1 & 1 & 1 & & 1 & 1 & 1 & 1 & & 1 \\
\hline & & & & & & 1 & 1 & 1 & & & & 1 & 1 & 1 & 1 & &
\end{tabular} \begin{tabular}{|l|l|l|l|l|l|l|l|l|l|l|l|l|l|l|l|l|l|l|l|l|l|l|l|l|l|l|l|}
1 & & 1 & 1 & & 1 & 1 & 1 & 1 & 1 & 1 & 1 & 1 & 1 & 1 & & & 1 & 1 & 1 & 1 & 1 & 1 & 1 & 1 & 1 & 1 \\
\hline
\end{tabular}

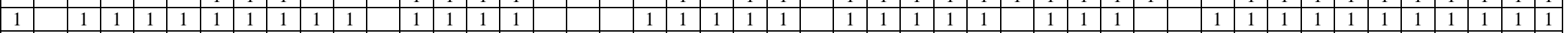

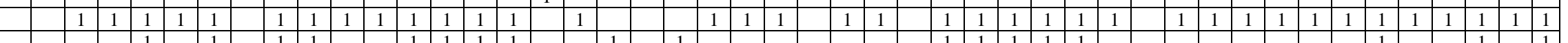

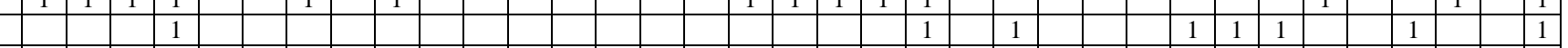

Ireland

Israel

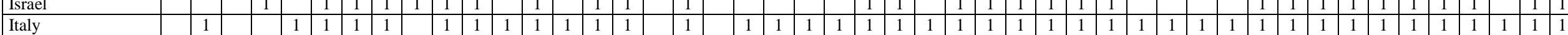

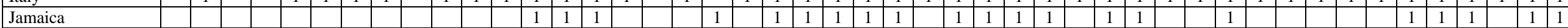

Japan

\begin{tabular}{l}
\hline Jordan \\
\hline
\end{tabular}

Kazakhstan

Kenya

\begin{tabular}{ll}
\hline Korea \\
\hline Kuwait \\
\hline
\end{tabular}

Kuwait

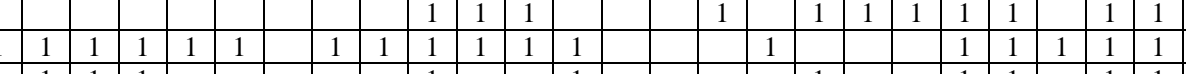
\begin{tabular}{llllllllllllllllllll} 
& & & & 1 & 1 & 1 & 1 & 1 & 1 & & 1 & 1 & 1 & 1 & 1 & 1 \\
& & & & 1 & 1 & 1 & 1 & & & & & & 1 & & & 1 \\
\hline & & & 1 & 1 & 1 & 1 & 1 & 1 & 1 & 1 & 1 & 1 & 1 & 1 & 1 \\
& & 1 & & & 1 & 1 & 1 & & 1 & 1 & & 1 & 1 & & & 1 \\
\hline & 1 & & & 1 & 1 & 1 & 1 & 1 & 1 & 1 & 1 & 1 & 1 & 1 & 1 & 1
\end{tabular} $\begin{array}{lll}1 & & \\ 1 & & \\ 1 & & \end{array}$ \begin{tabular}{lll|l|l|} 
& 1 & & \\
& & 1 & \\
& & 1 & \\
& & & \\
1 & 1 & &
\end{tabular} \begin{tabular}{lllllllll|l|l|l}
1 & 1 & 1 & 1 & 1 & & & & \\
1 & 1 & & 1 & 1 & 1 & 1 & 1 & \\
1 & & & & & & & &
\end{tabular} \begin{tabular}{|l|l|l|l|l|l|l|l|l|l|l|l|l|l|l|}
\hline 1 & 1 & & & 1 & 1 & 1 & 1 & & & & & & & \\
\hline 1 & & 1 & & & & 1 & 1 & 1 & & & 1 & & & 1 \\
\hline
\end{tabular} 
8 Kyrgyz Republic

Lao PDR

\begin{tabular}{l}
\hline Latvia \\
\hline Leban
\end{tabular}

Lebanon

Lesotho

\begin{tabular}{|l}
\hline Liberia \\
\hline Lithuania \\
\hline
\end{tabular}

\begin{tabular}{|l}
\hline Lithuania \\
\hline Macedonia \\
\hline
\end{tabular}

Macedonia

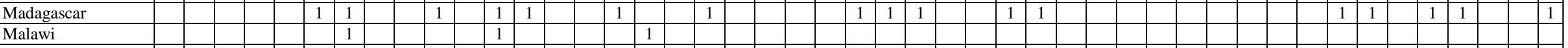

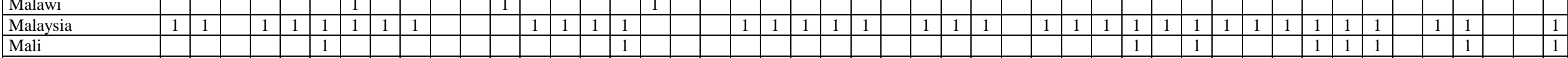

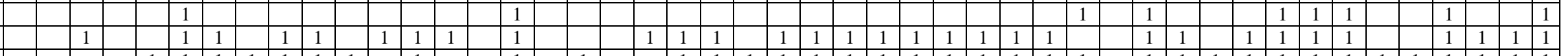

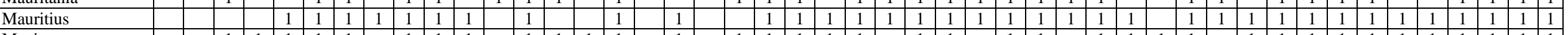

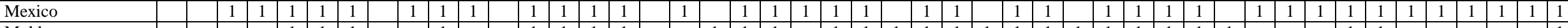

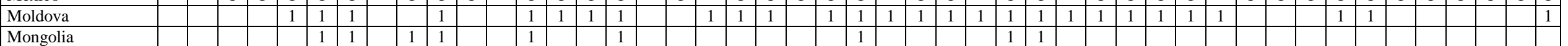

\begin{tabular}{l}
\hline Morocco \\
\hline
\end{tabular}

Mozambique \begin{tabular}{ll|l|l|l|l|l|l|l|l|l|l|l|l|l|l|l|l}
\hline & & & & & & & & & & & 1 & & & 1 \\
\hline
\end{tabular}

Namibia

Nepal

Netherlands

New Zealand

Nicaragua

Nicaragu

\begin{tabular}{l} 
Niger \\
\hline Nigeria \\
\hline Norway \\
\hline
\end{tabular}

Norway

Oman

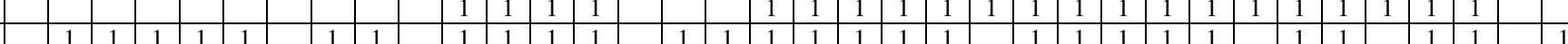

Panama

Papua New Guinea

Paraguay

Peru

\begin{tabular}{|l}
\hline Philippines \\
\hline Poland \\
\hline
\end{tabular}

Poland

\begin{tabular}{|l}
\hline Portugal \\
\hline Pugna
\end{tabular}

\begin{tabular}{|l|}
\hline Puerto Rico \\
\hline Romana
\end{tabular} \begin{tabular}{lllllll|l|ll|}
\hline & & & 1 & & 1 & 1 & & 1 & 1 \\
\hline
\end{tabular} \begin{tabular}{l|l|l|l|l} 
& 1 & 1 & & 1 \\
1 & 1 & & & 1 \\
\hline
\end{tabular}

\begin{tabular}{l|l|l|l|l|l|l|l|l|l|l|l|l|l|l|l|l|l|l|l|l|l|l|l|l|l|l}
1 & 1 & & & & & & & & & & & & & & 1 & 1 & & & & & & \\
1 & & 1 & & & 1 & 1 & & 1 & 1 & & 1 & 1 & 1 & 1 & 1 & 1 & 1 & \\
1 & 1 & & & 1 & 1 & 1 & & & 1 & 1 & & & & & &
\end{tabular}

Romania

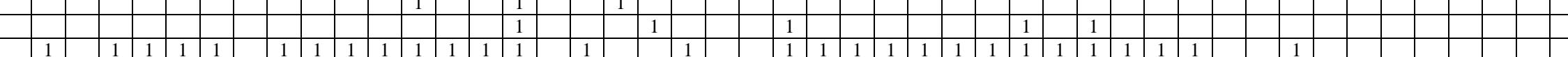

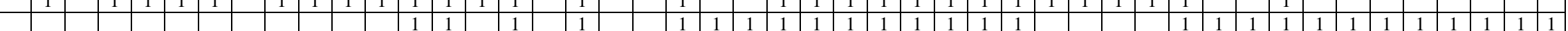

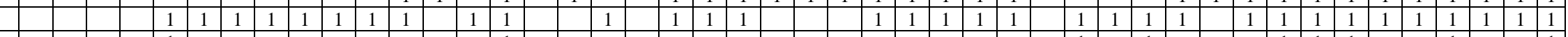

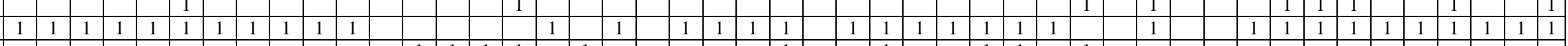

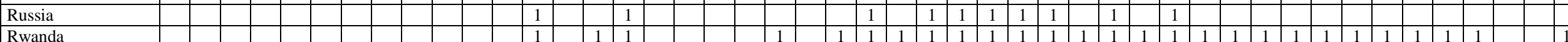

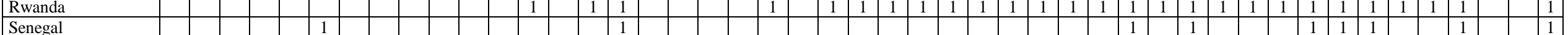

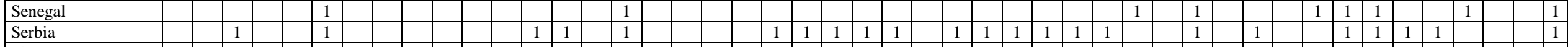

Sierra Leone

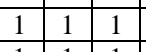

Singapore

Slovenia

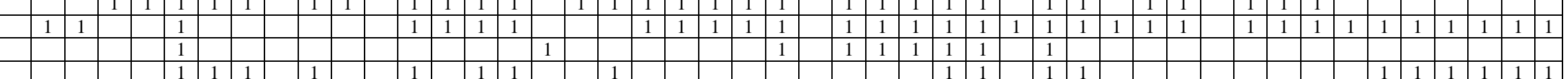

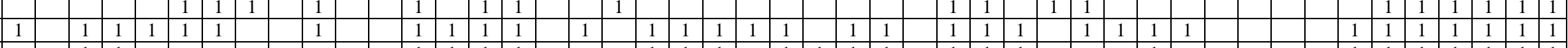

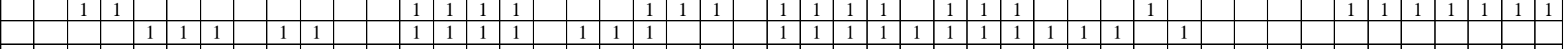

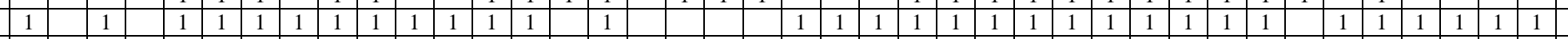

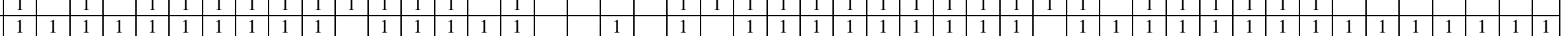
\begin{tabular}{l|l|l|l|l|l|l|l}
\hline & 1 & & & 1 & \\
1 & & & 1 & & 1 & 1
\end{tabular}

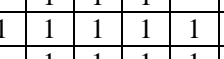

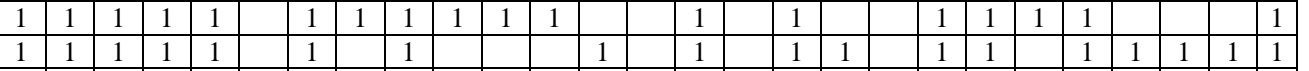


\begin{tabular}{ll|l|l|l|l|l|l|l|l|l|l|l|l|l|l|l|l|l|l|l|l|l|l|} 
& 1 & 1 & 1 & 1 & 1 & 1 & 1 & 1 & 1 & 1 & 1 & 1 & 1 & 1 & 1 & 1 & & 1 & 1 & 1 & 1 & 1 & 1 \\
\hline
\end{tabular}

Spain

Sri Lanka

St. Kitts and Nevis

\begin{tabular}{|l} 
St. Lucia \\
\hline St. Vincent an
\end{tabular}

St. Vincent and the Grenadines

Sudan

Swaziland

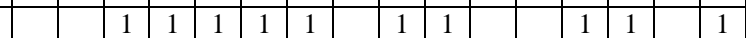

\begin{tabular}{l} 
Sweden \\
\hline Switerland \\
\hline
\end{tabular}

Switzerland

\begin{tabular}{llllllllll|l|l|l|l|l|l|}
\hline & & & & & & & & & & & 1 & & & 1 \\
\hline
\end{tabular} \begin{tabular}{|ll|l|l|l|l|l|l|l|l|l|l|l|l|l|}
\hline & 1 & 1 & & & 1 & 1 & & & 1 & & & & & \\
\hline
\end{tabular}

\begin{tabular}{ll|l|l|}
1 & & \\
\hline & 1 &
\end{tabular}

\section{\begin{tabular}{|llllllllllllllll}
\hline & & & & & & & & & & & & & \\
& & 1 & 1 & 1 & 1 & 1 & 1 & 1 & 1 & 1 & 1 & 1 & & \\
\hline
\end{tabular}}

\begin{tabular}{ll} 
Syria \\
\hline Taiwan \\
\hline Tajistan
\end{tabular}

Taiwan

\begin{tabular}{lll|l|l|l|l|l|l|l|l|llll}
1 & & & & & & & & & 1 & 1 & 1 & 1 \\
\hline
\end{tabular} \begin{tabular}{l|l|l|l|l|l} 
& 1 & & 1 & 1 \\
\hline
\end{tabular}

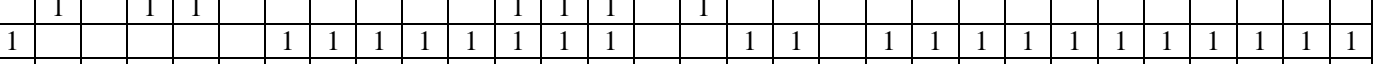
\begin{tabular}{lllllllllllllllllll|}
1 & & 1 & 1 & 1 & 1 & 1 & 1 & 1 & 1 & 1 & 1 & 1 & 1 \\
\hline
\end{tabular}

Tanzani

Thailan

Togo

\begin{tabular}{l|l|l|l|l|l|l|l|l|l|l|l}
1 & 1 & & 1 & 1 & 1 & 1 & 1 & 1 & 1 & 1 & \\
\hline & 1 & & & 1 & & & & & & 1 & \\
\hline
\end{tabular}

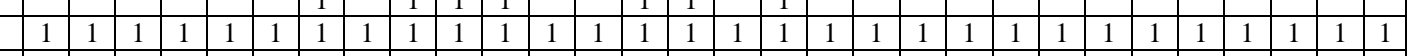

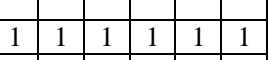
\begin{tabular}{l|l|l|l|}
1 & 1 & 1 & 1 \\
\hline
\end{tabular} $\begin{array}{lllllllllllllllll} & 1 & 1 & 1 & 1 & 1 & 1 & 1 & 1 & 1 & 1 & 1 & 1 & 1 & 1 & 1 & 1 \\ 1 & & & & 1 & 1 & 1 & 1 & 1 & 1 & 1 & 1 & 1 & 1 & 1 & 1 & \end{array}$

\begin{tabular}{l|l|l|l|l|l} 
& & & & 1 \\
\hline 1 & 1 & 1 & 1 & \\
\hline & & & 1 &
\end{tabular}

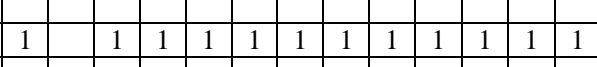

\begin{tabular}{|l|l|l|l|l|l|l|l|l|l|l|l|l|l|l|}
\hline & & 1 & & & & & & 1 & 1 & 1 & 1 & 1 & 1 & 1 \\
\hline 1 & & 1 & & & & 1 & 1 & 1 & & & 1 & & & 1 \\
\hline
\end{tabular}

Tunisia

\begin{tabular}{|l} 
Turkey \\
\hline Uganda \\
\hline Ukane \\
\hline
\end{tabular}

Uganda

United Arab Emirates

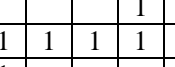

\begin{tabular}{l|l|l|l|l}
\hline & & & \\
& &
\end{tabular}

\begin{tabular}{l|l|l|l|l|l|} 
& 1 & & & & \\
1 & & & & 1 & \\
\hline
\end{tabular} \begin{tabular}{l|l|l|l|}
1 & & & \\
\hline & 1 & & \\
\hline & & 1
\end{tabular} $\begin{array}{lllllllllllllll}1 & 1 & & 1 & & 1 & 1 & 1 & 1 & 1 & 1 & 1 & \\ & & & & & & & & & & & & 1\end{array}$

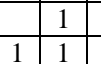

United Kingdo

United State \begin{tabular}{lllllll|l|l}
1 & 1 & 1 & & 1 & & \\
& 1 & 1 & & & 1 & & 1 \\
\hline
\end{tabular} \begin{tabular}{l|l|l|l}
\hline & 1 & 1 & \\
\hline & & &
\end{tabular}

\begin{tabular}{|l}
\hline Uruguay \\
\hline Uzbekistan \\
\hline
\end{tabular}

Uzbekistan \begin{tabular}{lllllllllllllllll}
1 & 1 & 1 & 1 & 1 & 1 & 1 & 1 & 1 & 1 & 1 & 1 & 1 & 1 & 1 & 1 \\
\hline
\end{tabular} 1 \begin{tabular}{l|l|l|l|l|l|l}
1 & & 1 & 1 & 1 & 1 & 1 \\
\hline
\end{tabular} \begin{tabular}{|l|l|l|l|l|l|l|l|l|l|l|l|l|l|l|l|l} 
& 1 & 1 & 1 & & & & & & & & & & & & & \\
\hline & & & 1 & & 1 & 1 & 1 & 1 & 1 & & 1 & 1 & & & 1 \\
\hline & & & & & & & & & & 1 & & & & 1 & \\
& 1 & 1 & 1 & & 1 & 1 & 1 & 1 & 1 & 1 & & 1 & & 1 & 1
\end{tabular} \begin{tabular}{l|l|l|l|l} 
& 1 & & \\
1 & & & \\
1 & 1 & &
\end{tabular}

Uzbekistan \begin{tabular}{llllllll|llllllllllll} 
& & & 1 & 1 & 1 & & 1 & 1 & 1 & 1 & & 1 & 1 & 1 & 1 \\
\hline
\end{tabular} \begin{tabular}{lllll|} 
& 1 & 1 & 1 & 1 \\
1 & 1 & 1 & 1 & 1 \\
\hline 1 & 1 & 1 & 1 & 1 \\
\hline & 1 & 1 & 1 & 1 \\
\hline
\end{tabular}

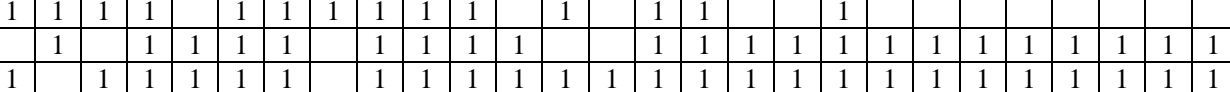

Vientm

Yemen $\begin{array}{llllllll}1 & 1 & 1 & 1 & & 1 & 1\end{array}$

\begin{tabular}{ll|l|l|l}
1 & & & 1 \\
1 & & & 1
\end{tabular}
\begin{tabular}{llllllllllllllllllllll} 
& 1 & 1 & 1 & 1 & 1 & 1 & 1 & 1 & 1 & 1 & 1 & 1 & 1 & 1 & 1 & 1 & 1 & 1 \\
\hline
\end{tabular}

\begin{tabular}{l} 
Zambia \\
\hline Zimbabwe \\
\hline
\end{tabular} Zimbabwe

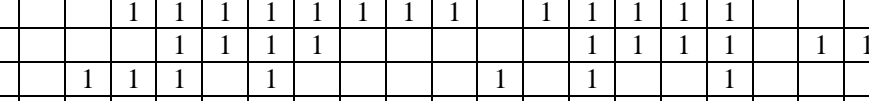
\begin{tabular}{llllllllllllllllllllllllllllll}
1 & 1 & 1 & 1 & 1 & & 1 & & 1 & 1 & 1 & & 1 & 1 & 1 & 1 & 1 & 1 & 1 & 1 & 1 & 1 & 1 & 1 & 1 & 1 & 1 \\
\hline & 1 & 1 & 1 & 1 & 1 & 1 & 1 & 1 & 1 & 1 & 1 & 1 & 1 & 1 & 1 & 1 & 1 & 1 & 1 & 1 & 1 & 1 & 1 & 1 & 1 & 1 \\
\hline
\end{tabular} \begin{tabular}{lllllllllllllllllllllllllllllllll}
1 & 1 & 1 & 1 & 1 & 1 & 1 & 1 & 1 & 1 & 1 & 1 & 1 & 1 & 1 & 1 & 1 & 1 & 1 & 1 & 1 & 1 & 1 & 1 & 1 & 1 & 1 \\
\hline 1 & & 1 & 1 & 1 & & & & 1 & & 1 & 1 & 1 & 1 & 1 & 1 & & & & 1 & & & & & & & 1 \\
\hline
\end{tabular}

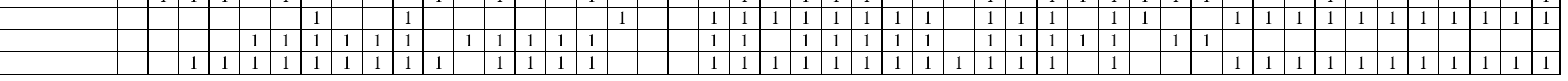

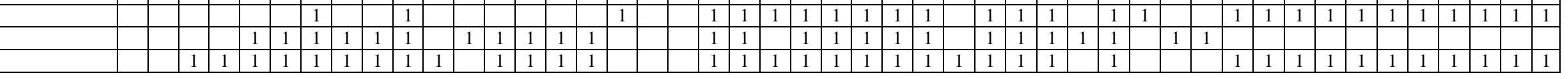

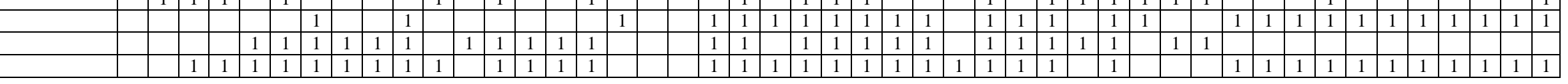

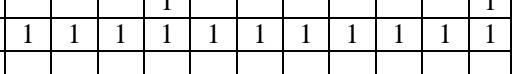


Table B - Indicators for evaluation of readiness to be protected - RP and inclusion to the protection scheme - IP

\begin{tabular}{|c|c|c|c|c|c|c|c|c|c|c|c|c|c|c|c|c|c|c|c|}
\hline $\begin{array}{l}\stackrel{8}{8} \\
\stackrel{\Xi}{E}\end{array}$ & 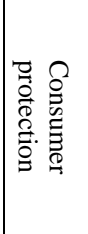 & 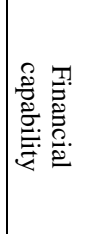 & 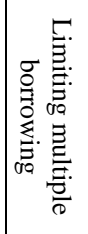 & 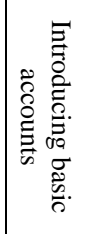 & 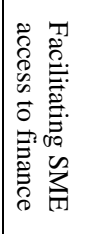 & 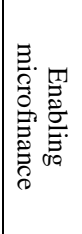 & 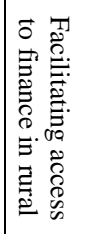 & 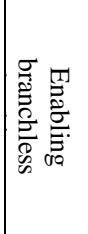 & 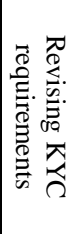 & 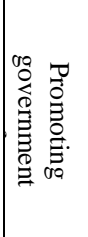 & 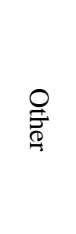 & 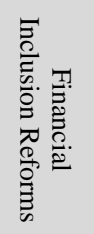 & 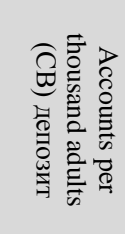 & 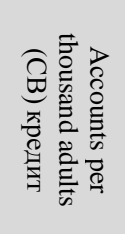 & 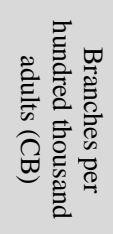 & 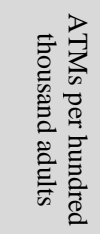 & 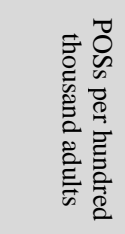 & 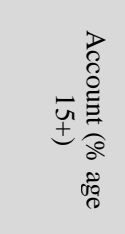 & 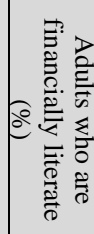 \\
\hline Afghanistan & 1.00 & & & & 1.00 & & & 1.00 & 1.00 & & & 4.00 & 83.85 & 3.32 & 2.00 & 0.38 & 2.75 & 9.005013 & 14 \\
\hline Albania & & & & & & & & & & & & 0.00 & 1278.63 & 107.53 & 22.29 & 31.11 & 183.45 & 28.26813 & 14 \\
\hline Algeria & 1.00 & 1.00 & 1.00 & & 1.00 & 1.00 & 1.00 & 1.00 & & 1.00 & & 8.00 & 736.56 & 681.52 & 5.30 & 5.75 & 2001.57 & 33.28611 & 33 \\
\hline Anguilla & & & & & & & & & 1.00 & & & 1.00 & 4426.58 & 790.84 & 55.07 & 137.67 & 3937.23 & 40.65 & 15 \\
\hline Antigua and Barbuda & & & & & & & & & & & & 0.00 & 2971.58 & 579.76 & 27.13 & 71.81 & 1881.31 & 40.65 & 20 \\
\hline Argentina & & 1.00 & & & 1.00 & 1.00 & 1.00 & & & 1.00 & & 5.00 & 906.29 & 526.33 & 13.20 & 36.85 & 2001.57 & 33.13022 & 28 \\
\hline Armenia & 1.00 & 1.00 & & & & & & 1.00 & 1.00 & & & 4.00 & 630.51 & 163.67 & 15.99 & 28.71 & 111.24 & 17.48687 & 18 \\
\hline Australia & & & & & & & & & & & & 0.00 & 2138.64 & 887.45 & 31.86 & 156.69 & 4039.64 & 99.06484 & 64 \\
\hline Austria & 1.00 & & & & & & & 1.00 & & & & 2.00 & 2402.71 & 887.45 & 27.54 & 118.86 & 4174.11 & 97.08174 & 53 \\
\hline Azerbaijan & 1.00 & 1.00 & & & & 1.00 & 1.00 & & 1.00 & & & 5.00 & 678.32 & 163.67 & 9.57 & 25.89 & 132.33 & 14.90085 & 36 \\
\hline Bangladesh & 1.00 & & & & & & & & & & & 1.00 & 316.67 & 41.37 & 5.16 & 80.69 & 2001.57 & 31.74365 & 19 \\
\hline Belarus & & 1.00 & & & & & & & & & & 1.00 & 625.87 & 163.67 & 45.00 & 32.76 & 336.04 & 58.60198 & 38 \\
\hline Belgium & 1.00 & & 1.00 & & 1.00 & & & & & & & 3.00 & 3968.95 & 887.45 & 48.49 & 138.32 & 1193.42 & 96.30613 & 55 \\
\hline Benin & & & & & & 1.00 & & 1.00 & & & & 2.00 & 99.85 & 681.52 & 2.89 & 80.69 & 2001.57 & 10.46394 & 37 \\
\hline Bolivia & 1.00 & 1.00 & & & 1.00 & 1.00 & 1.00 & & & & & 5.00 & 337.50 & 75.60 & 6.94 & 17.53 & 2001.57 & 28.02913 & 24 \\
\hline Bosnia and Herzegovina & & & & & & & & & 1.00 & & & 1.00 & 625.87 & 338.29 & 19.95 & 24.45 & 473.03 & 56.21161 & 27 \\
\hline Botswana & 1.00 & 1.00 & & & & & 1.00 & & & 1.00 & & 4.00 & 479.36 & 212.08 & 8.00 & 21.46 & 288.68 & 30.26001 & 52 \\
\hline Brazil & & 1.00 & & & 1.00 & & & & 1.00 & & & 3.00 & 1065.35 & 533.49 & 12.71 & 112.06 & 2247.41 & 55.86038 & 35 \\
\hline Bulgaria & 1.00 & 1.00 & & 1.00 & 1.00 & 1.00 & & & & & 1.00 & 6.00 & 2005.78 & 455.14 & 92.10 & 80.42 & 789.56 & 52.8249 & 35 \\
\hline Burkina Faso & & & & & & 1.00 & & 1.00 & & & & 2.00 & 67.61 & 681.52 & 1.82 & 80.69 & 2001.57 & 13.35309 & 33 \\
\hline Burundi & & & & & & & & & & & & 0.00 & 23.35 & 3.81 & 1.81 & 0.08 & 2001.57 & 7.237984 & 24 \\
\hline Cambodia & & & 1.00 & & 1.00 & & & & & 1.00 & & 3.00 & 95.83 & 27.15 & 3.92 & 4.19 & 34.13 & 3.659712 & 18 \\
\hline Canada & 1.00 & 1.00 & 1.00 & & 1.00 & & & & & & & 4.00 & 2138.64 & 887.45 & 24.11 & 218.55 & 2556.01 & 95.80464 & 68 \\
\hline Cape Verde & 1.00 & & & & & 1.00 & & & 1.00 & & & 3.00 & 1137.83 & 184.30 & 28.94 & 38.80 & 443.97 & 40.65 & 26 \\
\hline Chile & & & & & 1.00 & & & & & & & 1.00 & 729.76 & 647.26 & 14.92 & 58.74 & 486.07 & 42.17929 & 41 \\
\hline China & & & & & & & 1.00 & & & & & 1.00 & 987.28 & 681.52 & 4.25 & 80.69 & 2001.57 & 63.81731 & 28 \\
\hline Colombia & 1.00 & 1.00 & & 1.00 & & 1.00 & 1.00 & 1.00 & 1.00 & 1.00 & & 8.00 & 1267.44 & 469.75 & 14.30 & 29.56 & 441.06 & 30.4278 & 32 \\
\hline Costa Rica & & & & & & & & & 1.00 & & & 1.00 & 1353.83 & 602.52 & 23.30 & 181.52 & 1695.31 & 50.35873 & 35 \\
\hline Cote d'Ivoire & & & & & & 1.00 & & 1.00 & & & & 2.00 & 75.44 & 681.52 & 4.25 & 80.69 & 2001.57 & 40.65 & 35 \\
\hline Croatia & 1.00 & 1.00 & 1.00 & & & & & & 1.00 & & & 4.00 & 1441.51 & 681.52 & 34.54 & 95.89 & 2284.79 & 88.39102 & 44 \\
\hline
\end{tabular}




\begin{tabular}{|c|c|c|c|c|c|c|c|c|c|c|c|c|c|c|c|c|c|c|c|}
\hline Czech Republic & 1.00 & & & & & & & & & & & 1.00 & 1739.26 & 887.45 & 22.17 & 39.91 & 868.98 & 80.65119 & 58 \\
\hline Denmark & & & & & & & & & & & & 0.00 & 2138.64 & 887.45 & 45.36 & 147.58 & 2446.91 & 99.73679 & 71 \\
\hline Dominica & & & & & & & & & & & & 0.00 & 1608.76 & 219.40 & 14.48 & & 1032.01 & 40.65 & 28 \\
\hline Dominican Republic & & & & & 1.00 & & & & & 1.00 & & 2.00 & 987.28 & 245.09 & 9.98 & 27.11 & 2001.57 & 38.20467 & 35 \\
\hline Ecuador & 1.00 & 1.00 & 1.00 & 1.00 & 1.00 & 1.00 & 1.00 & 1.00 & & 1.00 & 1.00 & 10.00 & 569.24 & 300.60 & 1.61 & 12.80 & 2001.57 & 36.7355 & 30 \\
\hline El Salvador & & & 1.00 & & 1.00 & 1.00 & & 1.00 & & 1.00 & & 5.00 & 825.00 & 341.30 & 9.30 & 27.21 & 520.83 & 13.76462 & 21 \\
\hline Estonia & & & & & & & & & & & & 0.00 & 2669.14 & 985.49 & 18.68 & 88.25 & 1345.73 & 96.82428 & 54 \\
\hline Ethiopia & 1.00 & 1.00 & 1.00 & & 1.00 & 1.00 & 1.00 & & 1.00 & 1.00 & & 8.00 & 93.59 & 1.70 & 1.39 & 0.14 & 2001.57 & 40.65 & 32 \\
\hline Finland & 1.00 & & & & & & & & 1.00 & & & 2.00 & 2138.64 & 887.45 & 48.23 & 38.31 & 64.29 & 99.65125 & 63 \\
\hline France & 1.00 & & 1.00 & 1.00 & 1.00 & & & & 1.00 & & & 5.00 & 771.99 & 887.45 & 43.21 & 105.27 & 2456.92 & 96.98389 & 52 \\
\hline Gambia & 1.00 & 1.00 & 1.00 & & 1.00 & 1.00 & 1.00 & 1.00 & 1.00 & & & 8.00 & 283.20 & 31.11 & 6.70 & 3.04 & 2001.57 & 40.65 & 32 \\
\hline Georgia & & & & & & & & & & & & 0.00 & 626.63 & 313.19 & 18.57 & 37.00 & 211.32 & 32.98097 & 30 \\
\hline Germany & & & & & & & & & & & & 0.00 & 2138.64 & 887.45 & 15.91 & 112.18 & 836.53 & 98.13362 & 66 \\
\hline Ghana & & 1.00 & 1.00 & 1.00 & & & 1.00 & 1.00 & 1.00 & & & 6.00 & 332.61 & 651.21 & 5.11 & 4.77 & 2001.57 & 29.42535 & 32 \\
\hline Greece & & & & & & & & & & & & 0.00 & 2951.45 & 1208.83 & 41.50 & 80.58 & 3848.25 & 77.93986 & 45 \\
\hline Grenada & & & & & & & & & & & & 0.00 & 2556.00 & 355.90 & 32.97 & 47.47 & 873.01 & 40.65 & 32 \\
\hline Guatemala & 1.00 & & & & & & & & 1.00 & & & 2.00 & 1139.58 & 341.75 & 35.75 & 21.85 & 414.69 & 22.31888 & 26 \\
\hline Guinee Bissau & & & & & & 1.00 & & 1.00 & & & & 2.00 & 5.81 & 681.52 & 4.25 & 80.69 & 2001.57 & 40.65 & 30 \\
\hline Honduras & 1.00 & & & & & & & & 1.00 & & & 2.00 & 758.02 & 335.00 & 1.47 & 23.38 & 2001.57 & 20.51226 & 23 \\
\hline Hong Kong & & & & & & & & & & & 1.00 & 1.00 & 1138.64 & 887.45 & 21.19 & 147.58 & 2998.67 & 88.68604 & 43 \\
\hline Hungary & 1.00 & & 1.00 & & & & & & 1.00 & & 1.00 & 4.00 & 2058.27 & 681.52 & 18.31 & 55.62 & 831.30 & 72.67432 & 54 \\
\hline Iceland & & & & & & & & & & & & 0.00 & 1138.64 & 887.45 & 37.50 & 82.19 & 2998.67 & 85.48 & 65 \\
\hline India & & 1.00 & & 1.00 & 1.00 & 1.00 & 1.00 & 1.00 & & 1.00 & & 7.00 & 747.29 & 137.46 & 10.11 & 7.29 & 67.06 & 35.23184 & 24 \\
\hline Indonesia & 1.00 & 1.00 & & 1.00 & 1.00 & & 1.00 & & & & & 5.00 & 504.74 & 196.86 & 7.74 & 14.44 & 117.89 & 19.58199 & 32 \\
\hline Iran & 1.00 & & 1.00 & & 1.00 & 1.00 & & & 1.00 & 1.00 & & 6.00 & 987.28 & 681.52 & 29.15 & 29.79 & 2038.07 & 73.68385 & 20 \\
\hline Ireland & 1.00 & & & & 1.00 & & & & & & & 2.00 & 2181.85 & 887.45 & 57.27 & 95.74 & 2258.04 & 93.88835 & 55 \\
\hline Israel & 1.00 & & & & & & & & 1.00 & & 1.00 & 3.00 & 1055.71 & 926.12 & 19.85 & 104.33 & 2446.31 & 90.46864 & 68 \\
\hline Italy & 1.00 & & & 1.00 & & & & & & & & 2.00 & 774.99 & 701.10 & 52.04 & 97.81 & 2091.02 & 71.00853 & 37 \\
\hline Jamaica & & & & & & & & & & & & 0.00 & 1149.68 & 201.72 & 6.64 & 22.25 & 708.42 & 70.9915 & 33 \\
\hline Japan & 1.00 & & & & 1.00 & & & & & & & 2.00 & 7172.42 & 177.63 & 12.46 & 147.58 & 2446.31 & 96.42204 & 43 \\
\hline Jordan & 1.00 & & & & & & & & & & & 1.00 & 898.81 & 200.64 & 17.79 & 26.27 & 2001.57 & 25.4711 & 24 \\
\hline Kazakhstan & 1.00 & 1.00 & 1.00 & & 1.00 & & & & 1.00 & & & 5.00 & 625.87 & 253.14 & 2.79 & 52.10 & 170.86 & 42.1051 & 40 \\
\hline Kenya & & & & & 1.00 & 1.00 & 1.00 & 1.00 & & & & 4.00 & 381.62 & 75.48 & 4.38 & 8.28 & 2001.57 & 42.34346 & 38 \\
\hline Korea & 1.00 & 1.00 & & & 1.00 & 1.00 & 1.00 & & 1.00 & & & 6.00 & 987.28 & 681.52 & 12.27 & 80.69 & 2001.57 & 40.65 & 33 \\
\hline Kuwait & 1.00 & 1.00 & 1.00 & 1.00 & & & & & 1.00 & & & 5.00 & 987.28 & 681.52 & 16.47 & 53.42 & 1040.14 & 86.77325 & 44 \\
\hline Kyrgyz Republic & 1.00 & & & & 1.00 & 1.00 & 1.00 & & 1.00 & 1.00 & & 6.00 & 145.59 & 23.31 & 6.45 & 4.01 & 1152.40 & 3.757264 & 19 \\
\hline Lao PDR & & & & & 1.00 & 1.00 & 1.00 & & & & & 3.00 & 987.28 & 681.52 & 1.64 & 3.49 & 2001.57 & 26.77346 & 32 \\
\hline Latvia & & 1.00 & & & 1.00 & 1.00 & 1.00 & & & & & 4.00 & 1205.16 & 653.17 & 14.64 & 67.56 & 1219.32 & 89.65883 & 48 \\
\hline
\end{tabular}




\begin{tabular}{|c|c|c|c|c|c|c|c|c|c|c|c|c|c|c|c|c|c|c|c|}
\hline Lebanon & 1.00 & 1.00 & & & 1.00 & & & & 1.00 & & & 4.00 & 1371.98 & 519.89 & 28.83 & 39.32 & 1382.77 & 37.02733 & 44 \\
\hline Lesotho & & 1.00 & 1.00 & & 1.00 & 1.00 & 1.00 & 1.00 & & 1.00 & & 7.00 & 254.41 & 38.98 & 2.12 & 6.68 & 2001.57 & 18.49703 & 32 \\
\hline Liberia & 1.00 & & 1.00 & & 1.00 & 1.00 & 1.00 & & 1.00 & 1.00 & & 7.00 & 102.08 & 3.67 & 1.85 & 1.43 & 1.43 & 18.80147 & 32 \\
\hline Lithuania & 1.00 & & 1.00 & & & & & 1.00 & 1.00 & & & 4.00 & 4190.10 & 353.53 & 25.90 & 54.23 & 1362.28 & 73.7552 & 39 \\
\hline Macedonia & & & & & & & & & 1.00 & & & 1.00 & 625.87 & 463.86 & 25.69 & 50.06 & 1476.34 & 73.69894 & 21 \\
\hline Madagascar & & & 1.00 & & & 1.00 & 1.00 & & & & 1.00 & 4.00 & 987.28 & 681.52 & 1.49 & 80.69 & 2001.57 & 5.523223 & 38 \\
\hline Malawi & 1.00 & 1.00 & & & & 1.00 & 1.00 & 1.00 & & & & 5.00 & 163.44 & 16.52 & 2.16 & 2.65 & 4.44 & 16.54061 & 35 \\
\hline Malaysia & 1.00 & 1.00 & 1.00 & 1.00 & 1.00 & 1.00 & 1.00 & 1.00 & 1.00 & 1.00 & & 10.00 & 2063.33 & 963.60 & 11.44 & 53.99 & 1063.09 & 66.17381 & 36 \\
\hline Mali & & & & & & 1.00 & & 1.00 & & & & 2.00 & 116.02 & 681.52 & 3.48 & 80.69 & 2001.57 & 8.213853 & 33 \\
\hline Mauritania & & & & & & & & & & & & 0.00 & 987.28 & 681.52 & 3.89 & 80.69 & 2001.57 & 17.46182 & 33 \\
\hline Mauritius & 1.00 & & & & & & & & & & & 1.00 & 2109.04 & 479.24 & 20.11 & 39.09 & 763.80 & 80.12321 & 39 \\
\hline Mexico & 1.00 & & 1.00 & & & 1.00 & 1.00 & 1.00 & 1.00 & & 1.00 & 7.00 & 1096.76 & 681.52 & 14.67 & 44.80 & 592.14 & 27.42938 & 32 \\
\hline Moldova & 1.00 & & & & & & & & & & & 1.00 & 625.87 & 253.14 & 9.57 & 4.01 & 1153.21 & 18.06632 & 27 \\
\hline Mongolia & & & & & & & & & & & & 0.00 & 2089.32 & 259.66 & 53.99 & 15.10 & 194.13 & 77.71709 & 41 \\
\hline Montserrat & & & & & & & & & 1.00 & & & 1.00 & 3680.04 & 246.48 & 54.23 & 54.23 & 1111.71 & 40.65 & 32 \\
\hline Morocco & 1.00 & & 1.00 & 1.00 & 1.00 & & 1.00 & 1.00 & & & & 6.00 & 265.28 & 681.52 & 9.92 & 18.63 & 89.93 & 39.07011 & 32 \\
\hline Mozambique & 1.00 & & & 1.00 & & & & 1.00 & & & & 3.00 & 140.50 & 681.52 & 2.89 & 5.09 & 38.31 & 40.65 & 32 \\
\hline Namibia & & & & 1.00 & & & & & & & & 1.00 & 757.61 & 209.80 & 7.25 & 30.51 & 337.61 & 40.65 & 27 \\
\hline Nepal & & 1.00 & & & & 1.00 & 1.00 & 1.00 & 1.00 & & & 5.00 & 987.28 & 681.52 & 4.19 & 1.81 & 2001.57 & 25.30856 & 18 \\
\hline Netherlands & & & & & & & & & & & & 0.00 & 1765.79 & 1085.06 & 25.36 & 64.14 & 2343.41 & 98.65853 & 66 \\
\hline New Zealand & 1.00 & 1.00 & & & & & & & 1.00 & & & 3.00 & 1138.64 & 887.45 & 35.41 & 73.13 & 4268.13 & 96.458 & 61 \\
\hline Nicaragua & 1.00 & & & & & & & & 1.00 & & & 2.00 & 987.28 & 681.52 & 4.25 & 80.69 & 2001.57 & 99.43673 & 20 \\
\hline Niger & & & & & & 1.00 & & 1.00 & & & & 2.00 & 25.07 & 681.52 & 4.25 & 80.69 & 2001.57 & 14.21833 & 31 \\
\hline Nigeria & 1.00 & 1.00 & 1.00 & 1.00 & 1.00 & 1.00 & 1.00 & 1.00 & 1.00 & 1.00 & & 10.00 & 461.21 & 681.52 & 6.42 & 80.69 & 2001.57 & 29.66754 & 26 \\
\hline Norway & & & & & & & & & & & & 0.00 & 1138.64 & 887.45 & 34.49 & 56.85 & 3014.45 & 96.458 & 71 \\
\hline Oman & 1.00 & & 1.00 & 1.00 & 1.00 & & 1.00 & & 1.00 & 1.00 & & 7.00 & 1042.61 & 412.79 & 22.61 & 45.91 & 2001.57 & 73.60242 & 32 \\
\hline Pakistan & 1.00 & 1.00 & 1.00 & 1.00 & 1.00 & 1.00 & 1.00 & 1.00 & 1.00 & & & 9.00 & 229.49 & 34.67 & 8.68 & 4.06 & 48.98 & 10.3063 & 26 \\
\hline Panama & & 1.00 & 1.00 & & & & & & & & & 2.00 & 411.92 & 349.66 & 18.52 & 40.56 & 2001.57 & 24.9265 & 27 \\
\hline Papua New Guinea & & 1.00 & & & & 1.00 & 1.00 & & 1.00 & & & 4.00 & 987.28 & 681.52 & 1.71 & 80.69 & 2001.57 & 40.65 & 32 \\
\hline Paraguay & & 1.00 & & & & & & & 1.00 & & & 2.00 & 108.74 & 118.58 & 6.78 & 80.69 & 2001.57 & 21.72015 & 32 \\
\hline Peru & 1.00 & 1.00 & 1.00 & & & 1.00 & & 1.00 & 1.00 & & & 6.00 & 783.37 & 317.22 & 7.31 & 22.26 & 53.96 & 20.45869 & 28 \\
\hline Philippines & 1.00 & 1.00 & 1.00 & & 1.00 & 1.00 & 1.00 & 1.00 & 1.00 & & & 8.00 & 499.10 & 681.52 & 11.81 & 14.25 & 2001.57 & 26.55593 & 25 \\
\hline Poland & & & & & & & & & & & & 0.00 & 1626.41 & 681.52 & 32.21 & 49.14 & 666.71 & 70.19429 & 42 \\
\hline Portugal & 1.00 & & 1.00 & & 1.00 & 1.00 & & & 1.00 & & 1.00 & 6.00 & 1138.64 & 887.45 & 68.08 & 206.94 & 2444.61 & 81.22942 & 26 \\
\hline Puerto Rico & & 1.00 & & & & & & & & 1.00 & & 2.00 & 1300.23 & 887.45 & 15.72 & 40.23 & 1523.98 & 84.63 & 32 \\
\hline Romania & & & & & & & & & & & & 0.00 & 987.28 & 344.42 & 35.00 & 53.21 & 540.33 & 44.59163 & 22 \\
\hline Russia & & & & & 1.00 & 1.00 & 1.00 & 1.00 & & & & 4.00 & 625.87 & 253.14 & 2.62 & 76.51 & 293.05 & 48.17849 & 38 \\
\hline Rwanda & & & 1.00 & & 1.00 & 1.00 & 1.00 & 1.00 & & 1.00 & & 6.00 & 226.15 & 681.52 & 1.87 & 0.46 & 1.67 & 32.76382 & 26 \\
\hline
\end{tabular}




\begin{tabular}{|c|c|c|c|c|c|c|c|c|c|c|c|c|c|c|c|c|c|c|c|}
\hline Senegal & & & & & & 1.00 & & 1.00 & & & & 2.00 & 109.35 & 681.52 & 4.05 & 80.69 & 2001.57 & 5.821141 & 40 \\
\hline Serbia & & & & & & & & & 1.00 & & & 1.00 & 625.87 & 253.14 & 43.36 & 45.10 & 978.07 & 62.21622 & 38 \\
\hline Sierra Leone & & 1.00 & & & & 1.00 & & 1.00 & 1.00 & & & 4.00 & 98.62 & 9.68 & 2.31 & 1.14 & 1.52 & 15.34176 & 21 \\
\hline Singapore & 1.00 & & & & 1.00 & & & & 1.00 & & & 3.00 & 2236.25 & 914.55 & 10.54 & 49.83 & 2091.42 & 98.22189 & 59 \\
\hline Slovak Republic & & 1.00 & & & & & & 1.00 & 1.00 & & & 3.00 & 1857.83 & 887.45 & 26.64 & 49.34 & 713.06 & 79.58302 & 48 \\
\hline Slovenia & & & & & & & & & & & & 0.00 & 1380.42 & 887.45 & 10.99 & 101.67 & 1871.85 & 97.14372 & 44 \\
\hline South Africa & & & & & & & & & & & & 0.00 & 839.13 & 681.52 & 8.00 & 52.41 & 89086.84 & 53.64507 & 42 \\
\hline Spain & 1.00 & 1.00 & & & & & & & & & & 2.00 & 780.47 & 339.46 & 38.19 & 154.76 & 3711.27 & 93.2776 & 49 \\
\hline Sri Lanka & 1.00 & 1.00 & & & 1.00 & & 1.00 & 1.00 & 1.00 & & & 6.00 & 1891.74 & 681.52 & 9.05 & 12.29 & 2001.57 & 68.52617 & 35 \\
\hline St. Kitts and Nevis & & & & & & & & & 1.00 & & & 1.00 & 4366.64 & 663.74 & 57.44 & 94.61 & 2328.02 & 40.65 & 32 \\
\hline St. Lucia & & & & & & & & & & & & 0.00 & 2504.70 & 373.31 & 18.48 & 31.33 & 902.14 & 40.65 & 32 \\
\hline St. Vincent and the Grenadines & & & & & & & & & & & & 0.00 & 1690.53 & 256.82 & 15.12 & 23.94 & 656.47 & 40.65 & 32 \\
\hline Sudan & & & 1.00 & & 1.00 & 1.00 & 1.00 & 1.00 & 1.00 & & & 6.00 & 987.28 & 681.52 & 4.25 & 2.03 & 5.60 & 6.899798 & 21 \\
\hline Swaziland & 1.00 & & 1.00 & & 1.00 & & 1.00 & & 1.00 & 1.00 & 1.00 & 7.00 & 236.11 & 70.15 & 2.85 & 18.68 & 81.00 & 28.56944 & 32 \\
\hline Sweden & & & & & & & & & & & & 0.00 & 1138.64 & 887.45 & 25.87 & 36.63 & 2444.61 & 98.99195 & 71 \\
\hline Switzerland & 1.00 & & & & & & & & 1.00 & & & 2.00 & 1138.64 & 887.45 & 48.23 & 93.06 & 1985.35 & 96.46 & 57 \\
\hline Syria & & 1.00 & 1.00 & 1.00 & 1.00 & 1.00 & 1.00 & & & 1.00 & & 7.00 & 191.47 & 72.94 & 2.42 & 2.67 & 2.22 & 23.25309 & 32 \\
\hline Taiwan & 1.00 & 1.00 & & & 1.00 & & & & 1.00 & & & 4.00 & 5187.77 & 635.68 & 17.95 & 132.75 & 1141.95 & 87.3149 & 37 \\
\hline Tajikistan & 1.00 & 1.00 & 1.00 & & 1.00 & 1.00 & 1.00 & 1.00 & 1.00 & & & 8.00 & 30.98 & 253.14 & 3.91 & 3.98 & 2.11 & 2.534857 & 17 \\
\hline Tanzania & & & & & 1.00 & 1.00 & & & & & & 2.00 & 987.28 & 681.52 & 1.84 & 3.44 & 16.14 & 17.25777 & 40 \\
\hline Thailand & & 1.00 & & & 1.00 & 1.00 & 1.00 & & 1.00 & 1.00 & & 6.00 & 1448.84 & 272.45 & 11.04 & 71.32 & 2001.57 & 72.66644 & 27 \\
\hline Togo & & & & & & 1.00 & & 1.00 & & & & 2.00 & 186.73 & 681.52 & 3.47 & 80.69 & 2001.57 & 10.18524 & 38 \\
\hline Tunisia & & & & & & & & & & & & 0.00 & 639.66 & 193.46 & 14.40 & 17.26 & 121.65 & 42.52 & 45 \\
\hline Turkey & & & & & 1.00 & & & 1.00 & & & & 2.00 & 1661.21 & 360.67 & 17.77 & 44.25 & 3232.79 & 57.60143 & 24 \\
\hline Uganda & & 1.00 & 1.00 & & & 1.00 & 1.00 & 1.00 & & 1.00 & & 6.00 & 173.21 & 25.21 & 2.25 & 3.29 & 4.53 & 20.46142 & 34 \\
\hline Ukraine & 1.00 & 1.00 & 1.00 & & & & & & & & & 3.00 & 3145.32 & 253.14 & 2.74 & 71.34 & 187.17 & 41.26857 & 40 \\
\hline United Arab Emirates & & & & & & & & & & & & 0.00 & 1750.65 & 651.14 & 20.85 & 99.27 & 2001.57 & 59.73237 & 38 \\
\hline United Kingdom & 1.00 & 1.00 & 1.00 & & 1.00 & 1.00 & 1.00 & & & 1.00 & & 7.00 & 2923.25 & 887.45 & 20.74 & 122.84 & 2330.70 & 97.20129 & 67 \\
\hline United States & 1.00 & & & & & & & & & & & 1.00 & 2021.89 & 887.45 & 36.33 & 175.69 & 2444.61 & 87.95786 & 57 \\
\hline Uruguay & 1.00 & 1.00 & & & 1.00 & 1.00 & & & & & 1.00 & 5.00 & 529.39 & 428.56 & 12.62 & 30.59 & 272.76 & 23.5426 & 45 \\
\hline Uzbekistan & & & & 1.00 & 1.00 & 1.00 & 1.00 & & & & & 4.00 & 914.92 & 253.14 & 4.25 & 1.05 & 317.50 & 22.50392 & 21 \\
\hline Venezuela & 1.00 & & & 1.00 & 1.00 & & 1.00 & 1.00 & & & 1.00 & 6.00 & 1246.39 & 681.52 & 4.25 & 28.19 & 2001.57 & 44.11666 & 25 \\
\hline Vietnam & & & 1.00 & & & 1.00 & 1.00 & 1.00 & & 1.00 & & 5.00 & 987.28 & 681.52 & 3.21 & 80.69 & 2001.57 & 21.36949 & 24 \\
\hline Yemen & & & & & & & & & & & & 0.00 & 103.90 & 8.25 & 1.80 & 2.84 & 16.98 & 3.659954 & 13 \\
\hline Zambia & & & & & 1.00 & & 1.00 & & & & & 2.00 & 27.59 & 17.81 & 3.64 & 6.35 & 13.11 & 21.36491 & 40 \\
\hline Zimbabwe & 1.00 & & & 1.00 & 1.00 & 1.00 & 1.00 & 1.00 & 1.00 & 1.00 & & 8.00 & 144.36 & 20.53 & 4.25 & 7.83 & 33.69 & 39.65121 & 41 \\
\hline
\end{tabular}

